1986

\title{
Predicting Returns in the Stock and Bond Markets
}

Donald B. Keim

University of Pennsylvania

Robert F. Stambaugh

University of Pennsy/vania

Follow this and additional works at: https://repository.upenn.edu/fnce_papers

Part of the Finance Commons, and the Finance and Financial Management Commons

\section{Recommended Citation}

Keim, D. B., \& Stambaugh, R. F. (1986). Predicting Returns in the Stock and Bond Markets. Journal of Financial Economics, 17 (2), 357-390. http://dx.doi.org/10.1016/0304-405X(86)90070-X

At the time of publication, author Robert F. Stambaugh was affiliated with the University of Chicago. Currently, he is a faculty member at the Wharton School at the University of Pennsylvania.

This paper is posted at ScholarlyCommons. https://repository.upenn.edu/fnce_papers/384

For more information, please contact repository@pobox.upenn.edu. 


\title{
Predicting Returns in the Stock and Bond Markets
}

\author{
Abstract \\ Several predetermined variables that reflect levels of bond and stock prices appear to predict returns on \\ common stocks of firms of various sizes, long-term bonds of various default risks, and default-free bonds \\ of various maturities. The returns on small-firm stocks and low-grade bonds are more highly correlated in \\ January than in the rest of the year with previous levels of asset prices, especially prices of small-firm \\ stocks. Seasonality is found in several conditional risk measures, but such seasonality is unlikely to \\ explain, and in some cases is opposite to, the seasonal found in mean returns.

\section{Disciplines} \\ Finance | Finance and Financial Management

\section{Comments} \\ At the time of publication, author Robert F. Stambaugh was affiliated with the University of Chicago. \\ Currently, he is a faculty member at the Wharton School at the University of Pennsylvania.
}




\title{
PREDICTING RETURNS IN THE STOCK AND BOND MARKETS
}

\author{
by \\ Donald B. Keim \& Robert F. Stambaugh \\ \# 15-85
}

RODNEY L. WHITE CENTER FOR FINANCIAL RESEARCH The Wharton School University of Pennsylvania Philadelphia, PA 19104

The contents of this paper are the sole responsibility of the author(s). 


\section{Predicting Returns in the Stock and Bond Markets* \\ by \\ Donald B. Keim ${ }^{+}$ \\ and \\ Robert F. Stambaugh ${ }^{++}$}

First Draft: July 1984

Revised: June 1985

Comments welcome

\footnotetext{
"We thank Nai-Fu Chen, Eugene Fama, Wayne Ferson, Jay Ritter, Krishna Ramaswamy, G. William Schwert, and participants in workshops at the University of Chicago, Northwestern University, and the University of Pennsylvania for helpful comments. Financial support from the Center for Research in Security Prices and the Institute for Quantitative Research in Finance is gratefully acknowledged.

+Assistant Professor of Finance, The Wharton School, University of Pennsylvania.

${ }^{++}$Associate Professor of Finance, Graduate School of Business, University of Chicago.
} 


\section{Abstract}

We find that several ex ante observable variables based on asset price levels predict ex post risk premiums on common stocks of NYSE firms of various sizes, long-term bonds of various default risks, and U.S. Government bonds of various maturities. The predictive ability is consistent over the 52-year sample period from 1927 through 1978. Ex post premiums on small-firm stocks and low-grade bonds are more sensitive in January than in the rest of the year to ex ante levels of asset prices, especially prices of small firms. We consider the possibility that the significantly higher January returns on these stocks and bonds are associated in part with increased risk around the turn of the year. 


\section{Introduction}

A question of long-standing interest to both academics and practitioners is whether returns on risky assets are predictable. In other words, do expectations about rates of return change over time? We ask, more specifically, whether there are ex ante observable variables that reliably predict ex post "risk premiums," defined as rates of return in excess of the short term interest rate.

To find that expected risk premiums on many assets change predictably with a few common variables would complement nicely much of modern finance theory. Asset pricing theories often relate (conditional) expected risk premiums to (conditional) covariances in models of the form

$$
E\left(r_{i}\right)=\sum_{k=1}^{K} B_{i k} \gamma_{k},
$$

where $B_{i k}$ is the covariance between the return on asset $i$ and the kth factor of common risk, and $\gamma_{k}$ is the "factor premium" for this source of risk. 1 If the ${ }^{i k}$ 's are relatively constant over time, then changes in expected risk premiums for all assets are driven primarily by changes in the $K$ factor premiums, and $K$ is presumed to be much less than the number of assets. The theories themselves do not, however, specify which ex ante observable variables might proxy for the factor premiums.

Previous evidence of ex ante variables that predict risk premiums is confined primarily to specific types of assets and specific time periods. For example, a number of researchers have found that excess returns on common stocks are negatively correlated with measures of expected inflation during the post-1953 period, but this result does not generalize to other types of assets or to other subperiods. 2 Indeed, Eama (1981) argues that the observed 
correlation is spurious. What we lack is evidence that one or several variables consistently predict risk premiums on a wide array of assets over a long period of time. There have been steps in that direction, however. Recently, Campbell (1984) finds that, in the 1959-1978 period, several measures constructed from interest rates on U.S. Government securities predict risk premiums on Treasury bills, 20-year Government bonds, and the value-weighted portfolio of New York Stock Exchange (NYSE) common stocks. 3 Some of the strongest and most perplexing evidence that expected risk premiums change in a predictable fashion is that, for more than fifty years, average returns on many stocks and corporate bonds have been significantly higher in January than in other months.

This study pursues the topic of changing expectations with two primary objectives. A simple valuation model suggests that levels of asset prices might be inversely related to expected future returns. Thus, our first objective is to construct variables that might proxy roughly for levels of asset prices and to investigate whether these variables predict risk premiums on a wide range of assets. The second objective is to investigate whether the seasonality found in (unconditional) average returns on many assets is associated with changes in conditional expectations given asset price levels.

We construct three ex ante observable variables--one from the bond market and two from the stock market--and find that they predict ex post risk premiums on common stocks of NYSE-1isted firms of various sizes, long-term bonds of various default risks, and U.S. Government bonds of various maturities. The same variables also predict differences between returns on assets of the same type, such as small stocks versus large stocks, low-grade versus high-grade bonds, and long-term versus short-term bonds. The bondmarket variable is the spread between yields on low-grade corporate bonds and 
one-month Treasury bills. The stock-market variables are (1) minus the logarithm of the ratio of the real Standard and Poor's Index to its previous historical average, and (2) minus the logarithm of share price, averaged across NYSE firms in the quintile of smallest market value. The three variables are related inversely to levels of asset prices, and, consistent with a simple valuation model, the variables are positively correlated with future returns.

We find that the ex ante variables, particularly the small-firm price variable, receive a significantly larger coefficient in January than in other months when predicting risk premiums on small-firm stocks and low-grade bonds. In essence, January returns on small-firm stocks and low-grade bonds are highest following years when asset prices are lowest. The regression relation using the small-firm variable is strong enough in January, in the post-1953 period, to explain nearly forty percent of the variance of the difference between returns on stocks of small and large firms in that month. These results suggest a tendency for increased risk of some sort around the turn of the year. A January seasonal that we find in the ex ante risk premiums of one-month private-issuer securities (e.g. commercial paper) is consistent with such a hypothesis. We also find some weak evidence that the frequency of large "bad news" events drops at the turn of the year for small firms. One interpretation of this evidence is that January returns were high during the sample period, at least in part, because rare negative outcomes, whose risk was perceived ex ante, were unrealized ex post.

The paper is organized as follows. Section 2 describes the ex ante variables, and section 3 investigates their ability to predict risk premiums on common stocks, long-term corporate bonds, and U.S. Government bonds of various maturities. Section 4 addresses the issue of seasonality, and section 5 investigates the behavior of one-step-ahead regression-based forecasts. 
Section 6 concludes the paper with some suggested directions for future research.

\section{The Ex Ante Variables}

Our basic objective is to ask whether current levels of asset prices can predict subsequent rates of return. An intuitive motivation for this investigation comes from a simple rational valuation model,

$$
p=\frac{E(c)}{d}
$$

where $p$ is an asset's price, $E(c)$ is the expected future cash flow, and $d$ is a discount rate. Versions of (2) have motivated numerous studies of asset price variability. For example, much of the "variance-bounds" literature asks whether prices vary too much to be explained only by changes in expected cash flows, given a constant discount rate [e.g., Leroy and Porter (1981), Shiller (1981), Grossman and Shiller (1981)]. Chen, Roll, and Ross (1983) use (2) to suggest that the factors contributing to stock-price variability can be viewed either as factors that change expected cash flows or as factors that change discount rates.

The discount rate depends, at least in part, on expected holding period returns for subsequent periods. In general, the discount rate will be an increasing function of expected future returns. ${ }^{4}$ If expected returns change over time, then variation in the price can reflect variation in expected returns (through the discount rate). Since much of the variation in prices is likely to arise from changes in expected cash flows, prices themselves are, at best, capable of providing the researcher with noisy measures of variation in expected returns. Nevertheless, whether this measurement error destroys any ability of prices to predict returns is an empirical question. 
To investigate the general question raised above, we attempt to construct variables that reflect levels of asset prices. Such an exercise is, by nature, somewhat arbitrary. Asset pricing theories generally do not point to specific variables as predictors. One could, in principle, use each asset's own price to predict that asset's future returns. 5 our focus, suggested by models as in (1), is on whether there exist common movements in expected returns or risk premiums. Therefore, we take a more aggregated approach. We construct three ex ante observable variables, one from the bond market and two from the stock market. All three variables are inversely related to the level of asset prices. Therefore, given the discussion above, these variables should be positively associated with future returns if expected returns change.

The first variable, from the bond market, is the difference between yields on long-term under-BAA-rated (low grade) corporate bonds and short term (approximately one-month) U.S. Treasury Bills. ${ }^{6}$ The annual bond yield is divided by 12 , and the yield spread is stated on a monthly basis.

This ex ante yield variable, which essentially reflects the level of lowgrade bond prices (relative to promised payments), shares its motivation with another bond-market variable proposed by Chen, Roll, and Ross (1983). They examine the correlation between stock returns and the contemporaneous (ex post) difference between returns on low-grade bonds and U.S. Government bonds. Chen, Roll, and Ross argue that changes in the relative prices of lowgrade bonds proxy for changes in expected risk premiums. We address the underlying proposition: that the level of prices is related to the level of expected risk premiums. Chen, Roll, and Ross find that stock returns are positively correlated with the contemporaneous bond return spread, and that result is consistent with an increase in expected risk premiums (low bond 
return spread) accompanying a decrease in the stock price (low stock return). Such a result is also consistent, however, with constant expected risk premiums. For example, the positive return correlation could simply reflect a positive correlation between expected cash flows on stocks and lowgrade bonds. The ex ante yield variable allows a direct test of whether expected risk premiums change.

The second variable, from the stock market, is minus the logarithm of the ratio of the real Standard and Poor's Composite Index (the "S \& P") to its previous long-run level. That is, we construct the variable $-\log \left(\mathrm{SP}_{t-1} / \overrightarrow{\mathrm{SP}}_{t-1}\right)$, where $S P_{t-1}$ is the level of the index at the end of month $t-1$, deflated by the Consumer Price Index, and $\overline{\mathrm{SP}}_{t-1}$ is the average of the year-end real index over the $45^{\circ}$ years prior to the year containing month $t-1$. Stating the variable relative to a historical average essentially produces a "detrended" series without incorporating ex post information. 7

Using the $S$ \& $P$ here provides an interesting complement to the variance bounds studies mentioned earlier. Those studies essentially ask whether all of the variation in the $S$ \& $P$ could arise from changes in expected cash flows (dividends), whereas this study asks whether any of the variation in the $S \& P$ is associated with changes in expected future returns (or discount rates).

The third variable is also from the stock market, but it attempts to capture the most volatile segment--small firms. Chan, Chen, and Hsieh (1983) report that returns on small firms exhibit the greatest ex post sensitivity to overall changes in expected risk premiums (as measured by the bond return spread described above). One simple hypothesis that is consistent with their evidence is that small stocks' own expected risk premiums are the most volatile. That is, when expected risk premiums on all assets change, the expected risk premiums on small stocks change the most, thereby producing the highest ex post return sensitivity. This argument also suggests that the 
level of small stock prices may provide a sensitive ex ante barometer of expected future risk premiums.

The data do not allow the same sort of ex ante historical detrending of a price (wealth) index as done above for the $S$ \& $P$. The small-stock price data begin at the same point where we begin analyzing returns. We instead construct a simpler measure: minus the natural logarithm of share price, averaged equally across the quintile of firms with the smallest market values on the NYSE. This variable exhibits no detectable trend, but it captures the variation in small-stock prices. The first difference in the series is essentially minus the capital gain return on an equally-weighted portfolio.

Figure 1 plots the monthly time series of the three ex ante variables described above. '(The two stock-price variables are rescaled in order to show all three series on the same graph.) The three series behave similarly, which suggests that one might view any of the three as proxying (inversely) for a general level of stock and bond prices. 8 As the regressions that follow will demonstrate, all three series appear to be positively associated with expected future risk premiums.

If expected returns change over time, particularly expected returns in excess of the riskless rate ( $r$ isk premiums), then asset pricing theories suggest that these changes should be associated with changes in $r$ isk. Specific measures of $r$ isk vary across pricing models, but a simple measure is the variance of the return on the market portfolio. Merton (1980) entertains a model in which the expected risk premium on the market is proportional to market variance, and he uses the variance of the $S \& P$ as a proxy for market variance. Figure 2 plots the monthly standard deviation of the $S \& P$ return, beginning January 1928, where the monthly standard deviation is the withinmonth standard deviation of daily returns. 9 
A comparison of figures 1 and 2 suggests at least some positive association between the ex ante variables and the $S \& P$ standard deviation. For example, standard deviations were high and asset prices were low (the three ex ante variables were high) in the early 1930's and again toward the end of that decade. ${ }^{10}$ Leverage-related bankruptcy risks may also be inversely related to the level of stock prices, especially if the levels of nominal debt vary slowly through time. This study does not investigate the ability of specific risk measures to predict returns. Our basic objective, as motivated earlier, is to investigate whether expected returns vary with levels of asset prices. Nevertheless, one might reasonably argue that such variation in expected returns at least partially reflects changes in risk.

\section{Predicting Risk Premiums with the Ex Ante Variables}

\subsection{Risk Premiums on Long-Term Bonds and Common Stocks}

We first examine risk premiums on seven portfolios formed from four bond and three stock categories that span a wide range of $r i s k$ and return. The portfolios are:

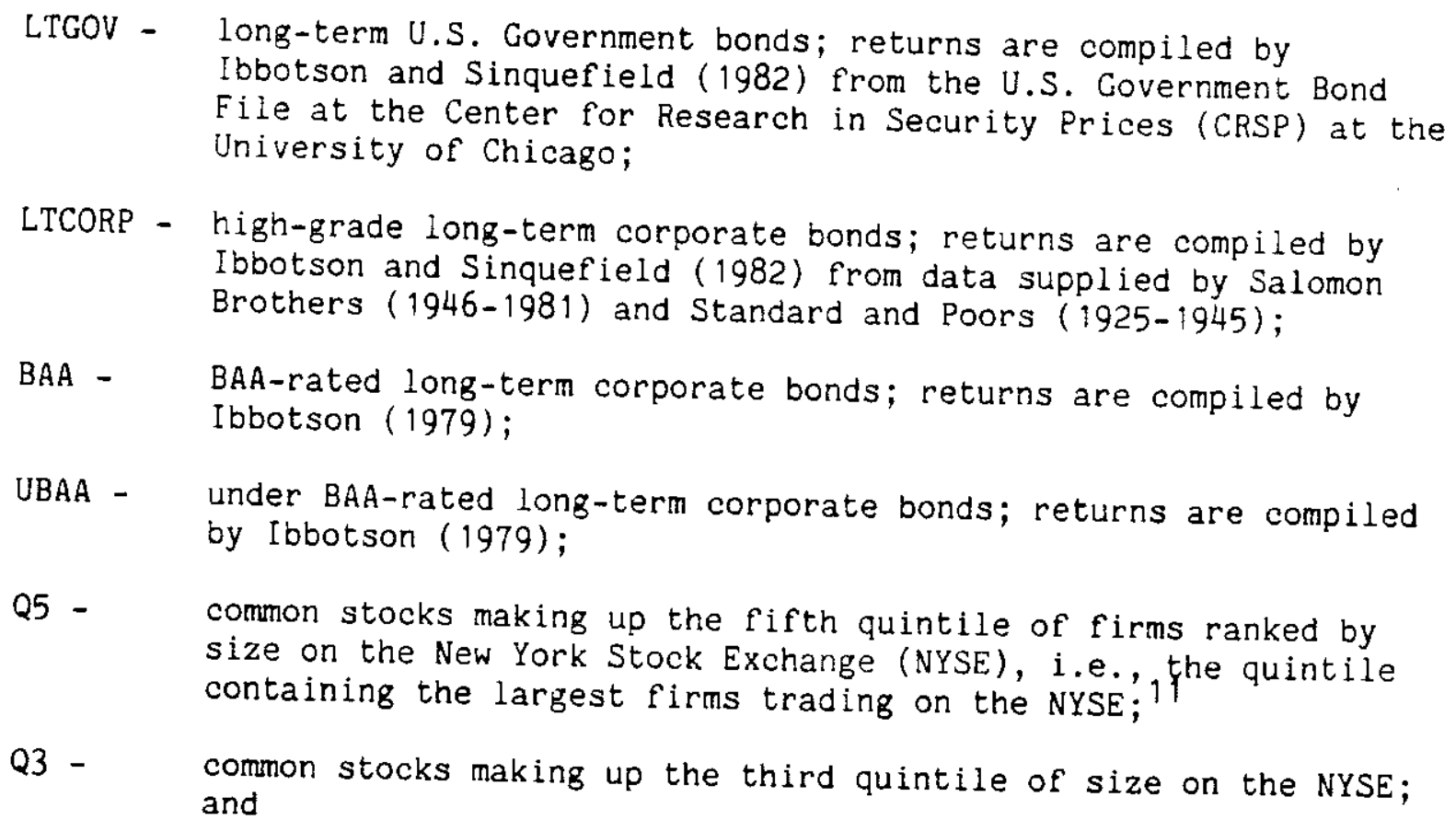


Q1 - common stocks making up the first quintile of size on the NYSE, i.e., the quintile containing the smallest firms trading on the NYSE.

Data availability confines us to the period from January 1927 to November 1978.12

Table 1 presents summary statistics for the monthly risk premiums in the overall period and in two approximately equal subperiods. Risk premiums are computed for each portfolio as the difference between the monthly return on the portfolio and the monthly return on the shortest-term Treasury bill with at least one month to maturity, as compiled by Ibbotson and Sinquefield (1982) from the CRSP U.S. Government Bond File. We list the assets by decreasing grades for the bonds and then by decreasing firm size for the stocks. Both the averages and the standard deviations of the risk premiums (columns 1 and 2) tend to increase monotonically as one moves down the columns, although there are several exceptions. The correlations between premiums on different assets exhibit a similar property, in that as assets become farther apart on the scale, correlations decline. For example, the Government bonds have their highest correlation with the high-grade corporate bonds and then display progressively lower correlations with the lower grade bonds and the stocks. The risk-premium autocorrelations are in general significantly larger than zero only at lags one and nine and are more pronounced for the lower grade bonds and smaller stocks. The first-order autocorrelations could reflect nonsynchronous trading [Fisher (1966)], or they could be one indication that expected premiums change over time.

\subsection{Regressions with Annual Risk Premiums}

Section 4 below documents January seasonals in the regression coefficients when monthly $r$ isk premiums are regressed on the ex ante variables. Before proceeding to those monthly regressions and our discussion 
of seasonality, we first examine annual risk premiums to focus on some basic results. Annual risk premiums are defined again as returns in excess of $T-B i l l$ returns, except here the monthly portfolio returns and the one-month $T$ Bill returns are compounded over 12 months.

We regress, using ordinary least squares, risk premiums for each of the seven portfolios on previous year-end values of the three ex ante variables: the yield variable $\left(\mathrm{y}_{\mathrm{UBA}}-\mathrm{y}_{\mathrm{TB}}\right)$, the $S$ \& $\mathrm{P}$ variable $(-\log \mathrm{SP} / \overline{\mathrm{SP}})$, and the small-firm variable $\left(\overline{-\log P_{Q 1}}\right)$. Table 2 displays results for the overall period and both subperiods. All t statistics shown are based on the standard errors proposed by white (1980), which are consistent in the presence of heteroscedasticity. Such adjusted standard errors are typically larger than the traditional estimates if the residual variance is positively correlated with the independent variable, and this tends to be true here (recall the comparison of figures 1 and 2). Thus, the t statistics shown are generally lower than their unadjusted counterparts.

In the overall period, the estimated coefficients on all three ex ante variables are positive for all assets, and, with few exceptions, the coefficients are reliably nonzero at usual levels of significance. An $F$ test of whether the coefficients jointly equal zero gives p-values of .003 or less. Adjusted $\mathrm{R}^{2}$ values range from .02 to .26 , but most values exceed 0.10. The subperiod regressions confirm the results for the overall period. All coefficient estimates in both subperiods are positive and of similar magnitudes to those in the overall period. Many of the coefficients are reliably nonzero, and the $F$ test of joint equality to zero gives p-values less than .007 in the first subperiod and between .036 and .080 in the second subperiod. Thus, the evidence appears to support the hypothesis that expected 
risk premiums change over time, and levels of asset prices evidently contain information about expected premiums.

Another interesting feature of the regressions is the pattern of the coefficients across assets. In the overall period, the coefficients on each of the ex ante variables increase monotonically with decreasing grade in the bond market and then with decreasing firm size in the stock market. An $F$ test of equality of the slope coefficients across the seven regressions produces $p$ values of .17 for the yeld variable, .20 for the S \& P variable, and .05 for the small-firm variable. The same pattern emerges in both subperiods, with the only real exception occurring for the yield-variable coefficients for the stocks in the second subperiod. These results suggest that assets with higher total return variances also tend to have higher variances of conditional expected returns associated with general asset price levels.

The regressions reported in this study share a problem common to many empirical studies in finance and economics. The independent variable, although predetermined with respect to the dependent variable, is stochastic and most 1 ikely correlated with past regression disturbances. This phenomenon leads to finite-sample bias in the regression coefficients and the $t$ statistics. In this application, where the correlation between the past regression disturbances and the independent variable is probably negative, the slope coefficient is biased upwards. The bias in the regressions reported in table 2 will be greatest when an asset's own previous price level is used to predict that asset's return (e.g. when the below-BAA return is regressed on the yield variable). When changes in the price-level variable are not highly correlated with the dependent variable, then the bias is small (e.g. when the Government bonds are regressed on the smal1-firm variable). ${ }^{13}$ Given the investigation reported in Stambaugh (1985), most of the $t$ statistics for the 
slope coefficients in table 2 still allow rejection of equality to zero at conventional significance levels, particularly in the bond regressions. The weakest results occur with the regressions of stock returns on the small-firm variable, but the results to be discussed later in section 4 indicate that the predictive ability in those regressions is strong in one month of the year (January). The latter results are not significantly affected by the bias described here.

We do not report the results of regressing risk premiums on two or more of the ex ante variables simultaneously. The variables are sufficiently collinear so that, in such regressions, no single variable produces reliably nonzero coefficients.

\subsection{Term Premiums on U.S. Government Bonds}

The previous section examines relatively long-lived assets whose future nominal payoffs possess different amounts of uncertainty. Table 2 begins with default-free Government bonds and then, roughly speaking, moves progressively through the spectrum of payoff uncertainty. The same long-term Government bonds also lie at the end of another asset spectrum: the default-free instruments of different maturities. This section investigates whether the variables that predict risk premiums in the previous section also predict risk premiums, or "term premiums," of U.S. Government bonds and notes with various maturities. A term premium is defined as the difference between a bond's return and the return on a one-month $T-b i l l$.

As explained earlier, table 2 presents results for annual risk premiums, since the regression coefficients for several of the assets examined there appear to be nonstationary across calendar months. Seasonality is investigated in the next section using monthly returns. The Government bond term premium regressions exhibit no detectable seasonality, so we immediately 
present results here based on monthly returns.

Our returns data consist of the file used by Fama (1984a). ${ }^{14}$ The file contains monthly returns, beginning in January 1953, on portfolios of notes and bonds (no bills) formed according to the ten maturity classifications listed in table 3 (second column). The first nine portfolios exclude "flower" bonds with special estate tax features. The tenth portfolio is the same Ibbotson-Sinquefield portfolio used in the previous section. That portfolio contains the bond with maturity closest to twenty years, but the highestpriced (relative to par) flower bond is chosen when no ordinary bond of sufficient maturity exists.

We regress term premiums for each of the ten bond portfolios on the three ex ante variables described earlier. The regressions are estimated by ordinary least squares, and the $t$ statistics again reflect standard errors based on the heteroscedasticity-consistent adjustment of white (1980). Table 3 displays the results. The coefficient estimates on all three variables are positive for all maturity classifications, and many are reliably nonzero. An $F$ test of whether the coefficients jointly equal zero gives $p-$ values of .15 for the yield variable, .10 for the $S \& P$ variable, and .02 for the small-firm variable. These results are consistent with the hypothesis that expected term premiums change over time. Moreover, the movements in expected term premiums are evidently associated, at least in part, with movements in the expected risk premiums on the other assets examined earlier. In other words, there appear to be common movements in expected returns for assets across a wide range of characteristics.

The (unconditional) average premiums, also shown in table 3 , are highest for the third portfolio (12 to 18 months) and then decrease as maturities lengthen. This pattern of average premiums in the post-1953 period is noted 
by Fama (1984a), but, as Fama concludes, the average premiums are not reliably different across maturities. 15 The variability of the longer-maturity bond returns makes it difficult to reject many hypotheses about the shape of the term structure.

The regression slope coefficients in table 3 tend to rise monotonically with maturity, unlike the average premiums, but here it is also difficult to reject equality of conditional expected premiums across portfolios, especially when the alternative hypothesis is vague or unspecified. For example, an $F$ test for equality of the slope coefficients against an unspecified alternative gives p-values of 0.16 or more. Testing for equality of slopes and intercepts gives similar results.

Some weak evidence against the null hypothesis of equality of the slope coefficients emerges when that hypothesis is tested against the alternative that the slope coefficients increase monotonically with maturity. If the ex ante variables proxy for a dimension of ex ante $r$ isk, then this alternative hypothesis essentially equates longer maturity to greater $r$ isk along that dimension. While one might argue that this is merely the alternative suggested by the data, we contend that it is also the alternative with the greatest a priori appeal. The simplest test suggested by this alternative is to compare the endpoints, i.e., the first and tenth portfolios. The last row of table 3 reports the results of regressing the difference in returns between the tenth and first portfolios on the ex ante variables. The slope coefficients in two of the three regressions are reliably positive.

Another approach to testing equality against this more specific alternative, and one that uses all ten portfolios, is to specify the regression coefficients as a function of maturity. We model the regression coefficients as a linear function of maturity and then test whether the slope of that relation is 
nonzero. In the case of the yield variable, for example, the slope coefficient in table 3 for portfolio $i\left(a_{\uparrow_{i}}\right)$ is specified as

$$
a_{1 i}=g_{0}+g_{1} m_{i} \quad, i=1, \ldots, 10,
$$

where and $m_{1}$ is the maturity (in months) for portfolio i. Eor the first nine portfolios we specify $m_{i}$ as the midpoint of the portfolio's maturity range, and for the tenth portfolio we set $m_{10}=240$. The parameters $g_{0}$ and $g_{1}$ are estimated in a system of seemly unrelated regressions subject to the joint (nonlinear) restriction in (3). ${ }^{16}$ The asymptotic $t$ statistics for $g_{1}$ range from 1.69 (for the $S \& P$ variable) to 2.08 (for the yield variable). Again, we find weak evidence to reject the hypothesis of coefficient equality in favor of the alternative that the coefficients increase with maturity.

If the slope coefficients do rise with maturity, then substituting sufficiently large values of the ex ante variables into the estimated regressions produces an upward sloping structure of conditional expected term premiums. Figure 3 plots the estimated regressions for all maturities in the case of the small-firm price variable. The average value of the small-firm variable for the $1953-78$ period is -2.47 , which, when substituted into the estimated regressions, gives the humped pattern of average premiums noted by Fama (1984a). During the same period, the small-firm variable ranges from -3.28 to -1.09 , and it reaches a maximum of 0.22 in the earlier 1927-52 period. The higher values (which correspond to lower actual stock prices) predict positively sloping term structures. For example, the 1927-52 average of -1.76 for the variable implies such a structure, which presents an out-ofsample forecast to be investigated. In the absence of a more complete model, however, such exercises must be viewed primarily as illustrating the general manner in which conditional expected premiums might change. If the cases of negative and downward sloping premiums are truly ex ante phenomena, then there 
are almost surely additional factors at work.

\section{Risk Premium Seasonality}

Previous studies report evidence of a positive January seasonal in bond returns [Schneeweiss and Woolridge (1979), Keim and Smirlock (1983)], and, especially, in stock returns [Rozeff and Kinney (1976), Keim (1983)]. Table 4 reports average monthly risk premiums (with t-statistics) separately in January and in non-January months for the seven long-term assets analyzed in section 3.2. The averages are computed using weighted least squares to estimate a regression of risk premiums on two dummy variables. The weights used in each regression are $1 / \sigma_{S P}$, the reciprocal of the within-month standard deviation of the $S \& P$ (displayed earlier in figure 2 ). We use weighted least squares here and in the subsequent monthly regressions in an attempt to obtain more efficient estimates in the face of significant heteroscedasticity. The $t$ statistics are again based on the white (1980) adjusted standard errors to allow for heteroscedasticity that may remain in the weighted regressions.

We find in table 4 the same January seasonality in risk premiums on many assets. With the exception of the long-term government bonds and the largest common stocks, mean risk premiums are significantly larger in January than in

non-January months. ${ }^{17}$ Further, the difference in means is more pronounced for lower quality bonds and smaller stocks. The F-statistic in column 4 for each period tests the hypothesis that monthly expected risk premiums are equal in non-January months; we can reject equality only for the below-BAA bonds, primarily due to the first subperiod.

That this seasonality has persisted for more than fifty years suggests that it relates to an ex ante phenomenon. In this section we report a January seasonal in the ability of our ex ante variables to predict risk premiums. 


\section{1 Seasonality and the Risk Premium Regressions}

We regress risk premiums on the ex ante variables and estimate the coefficients separately in January and in non-January months (again using weighted least squares). Although the coefficients on all three ex ante variables exhibit similar seasonality, the seasonal pattern is strongest for the coefficients on the small-firm price variable. In the interest of brevity, we report only the small-firm variable regressions for the remainder of the paper.

Table 5 reports the regression results for the overall period and for both subperiods. In the overall period, the coefficients on the small-firm variable are generally positive in January and in non-January months (the only negative coefficient is the January coefficient for high-grade corporate bonds), and the January coefficients are larger than the non-January coefficients (with the exception of government and high-grade corporate bonds). The non-January coefficients are significantly nonzero for the bond portfolios but not for the stock portfolios (the t statistics are 4.18 or more for the bonds but 1.56 or less for the stocks). The January coefficients are significantly nonzero for the lower grade bonds (BAA and below-BAA) and all but the largest stocks. As in the annual regressions (table 2), the coefficients on the ex ante variable tend to increase with decreasing grade for the bonds and with decreasing size for the stocks, but this pattern is more pronounced here for the January coefficients. As a result, the $t$ statistic of the difference between the January and non-January coefficients, $t\left(a_{1 j}-a_{1 r}\right)$, tends to increase as one moves down the column, and equality of the coefficients is rejected for the lowest-grade bonds and the smallest stocks. As in the annual regressions, the subperiod results show that the effects discussed above persist throughout the total period. 


\subsection{Seasonality and Differences in Returns between Assets of the Same Type}

Much of the literature on seasonality in stock returns focuses on seasonality in the so-called "size effect," defined as the difference in common stock return between the smallest and the largest firms [e.g., Keim (1983)]. The evidence in table 4 suggests that a similar seasonal exists in the difference in returns between low-quality bonds (e.g., UBAA) and high quality bonds (e.g., LTGOV). We regress differences in mean returns from the bond market ( $R_{U B A A}$ $\left.R_{\text {LTGOV }}\right)$ and the stock market $\left(R_{Q 1}-R_{Q 5}\right)$ on the small-firm price variable. Panel $A$ of table 6 reports the results for the bond returns and panel $B$ contains the results for the stock returns.

The coefficients on the small-firm variable in the overall period are, for both the bonds and the stocks, reliably positive in January (both $t$ statistics are approximately 3.5), but the non-January coefficients are not significantly greater than zero. Further, the January coefficient is significantly larger than the non-January coefficient in both regressions. The same results appear in both subperiods, although the effects are weak for the bonds in the second subperiod.

The regressions in table 6 , particularly those in panel $B$, demonstrate that the small-firm price variable and the January intercept dummy explain a substantial portion of the variation in the return differences. For example, these regressions explain 15\% of the variation in the difference in monthly stock returns between the smallest and largest firms over the 1928 to 1978 period and 35\% in the 1953 to 1978 subperiod. The explanatory power of the small-firm price variable when the regressions are computed in January only is also quite high. For example, the January $\mathrm{R}^{2}$ for the stocks is $24 \%$ for the total period and $38 \%$ for the later subperiod. 


\subsection{The Prospect of Seasonal Risk}

As the regressions reported above indicate, returns on all assets tend to be highest when stock prices are low, but this tendency is concentrated in January for many of the assets, especially stocks of small firms and low-grade bonds. If low stock prices serve as a rough measure of increased risk of some sort, then this seasonality in regression coefficients suggests that the risk accompanying a given level of stock prices tends to be highest around the turn of the year. ${ }^{18}$

An important question concerns the nature of the underlying risk. Estimates of the traditional risk measure, beta, display some seasonality, but not enough to explain the average-return seasonality in the context of the standard two-parameter model. ${ }^{19}$ Such time-series-based estimates of risk and return rely on sample frequencies of possible outcomes to infer the true probabilities of those outcomes. Unless one is willing to specify the nature of the underlying distribution (e.g., Normal), a very large sample may be required to assess correctly the probability of rare large-magnitude outcomes, such as very bad news. Pricing that is in fact rational given such possible outcomes could appear to be anomalous to the researcher whose sample contains none (or not enough) of those outcomes. This predicament has been dubbed the "peso problem" in the foreign exchange literature, where the rare outcome is a currency devaluation. 20

Because very bad news is by nature rare, it is difficult to make inferences about its probability based on sample frequency. An alternative is to isolate such risk by examining relative asset prices. Fama (1984b) examines "default premiums" on high-grade private-issuer money market instruments, such as A1-P1 commercial paper, prime quality domestic certificates of deposit, and prime quality bankers' acceptances. Default premiums are defined as returns in excess of identical-maturity T-Bills. Defaults on such instruments are quite 
rare, yet Fama finds average one-month ex ante default premiums of one percent or more (annualized) over the 1967 to 1984 period. Given the apparent liquidity of these instruments, it is difficult to attribute these premiums to anything other than the probability of default. This is most likely another illustration of the peso problem.

We entertain here the possibility that rare bad news events might have seasonally varying probabilities. We first investigate this possibility by examining the same ex ante one-month default premiums examined by Fama (1984b). ${ }^{21}$ Average default premiums on the private-issuer instruments are highest in January. For example, the average default premium on A1-P1 commercial paper for the period $1 / 1967$ to $2 / 1984$ is $1.17 \%$ (annualized) over all months, but January's average premium of $1.74 \%$ is the highest of all months. To test more formally for seasonality, we estimate the time series regression

$$
\begin{aligned}
\left(R_{C P}-R_{T B}\right)_{t} & =a_{0}+a_{1} d_{j t}+a_{2}\left(R_{C P}-R_{T B}\right)_{t-1}+u_{t}, \\
& .359-.695 \quad(4.41)(3.84) \quad(12.14)
\end{aligned}
$$

where $R_{C P}$ is the annualized percent return for one-month commercial paper, $R_{T B}$ is the annualized percent return on a one-month $T-B i l l$, and $d_{j t}=1$ if month $t$ is a January (zero otherwise). Results for all of the instruments are sufficiently similar so that results are reported for commercial paper only. The $t$ statistic of 3.84 on the January dummy indicates that investors in one-month instruments receive, other things equal, a significantly larger default premium in January. This result suggests that, if these instruments are priced rationally, the perceived ex ante risk of rare bad news (defaults) varies seasonally. 
The regression results reported in tables 5 and 6 are consistent with the hypothesis that expected returns and risk are higher (i) in January and (ii) in years when stock prices are low. However, if the appropriate measure of risk includes the possibility of rare bad-news outcomes, then the ex post sample results will tend to overstate the expected returns whenever the bad-news whose risk was perceived was not realized ex post. Thus, even though the expected returns might indeed vary in the manner suggested by the regressions, one should probably be cautious in viewing the magnitudes as ex ante quantities. To illustrate this possibility, imagine that the probability of a firm's announcing very bad news drops following the turn of the year. For example, if the probability of bad news, conditional on no announcement, takes a discrete drop at year end, then the stock price takes a discrete jump upward. This gives a large return to holding the stock over the turn of the year. Moreover, this return will be largest in years of greatest ex ante risk (or perhaps lowest stock prices).

We briefly describe here some evidence that at least weakly supports the hypothesis that the probability of very bad news drops following the turn of the year, especially for small firms. During the 1927-1981 period, delistings of small firms (lowest quintile) were most frequent in December (30 delistings) and least frequent in January (18 delistings), and delistings of small firms were accompanied by average monthly returns of $-19.2 \%{ }^{22}$ During the 1926-1982 period, individual small-firm returns less than $-50 \%$ were most frequent in December and returns less than $-40 \%$ were least frequent in January. (We exclude a firm's return in the month of delisting.) While these results are by no means conclusive, we suggest that, coupled with the earlier evidence on default premiums, they raise the possibility that seasonality of rare-outcometype risk may be an important ingredient of the return seasonality. 


\section{Forecasting Risk Premiums with the Small-Firm Price Variable}

The previous sections demonstrate that the small-firm price variable receives positive and significant coefficients in regressions with a wide array of asset returns. As a further check on the validity of these estimated regressions, this section investigates the ability of the regressions to make out-of-sample forecasts. Such an exercise, in addition to providing a somewhat more practical perspective, allows us to verify that the bias discussed earlier in section 3.2 does not significantly influence the reported regression results. An evaluation of forecasting ability outside our sample period would permit an analysis of only five or six years of data (when available). An alternative that allows for comparisons over a much longer period is to use 1927 through $1952^{\circ}$ as our initial base period and to examine forecasts over the 1953-1978 period. We compute "one-step-ahead" forecasts, which are based on parameters estimated using data for all periods up to but not including the forecast period.

Our objective is to compute one-step-ahead forecasts of risk premiums based on regression parameters estimated with the small-firm price variable and then to compare these with "naive" forecasts of risk premiums based on their historical means. Table 7 reports the percentage reduction in mean square forecast errors obtained from comparisons of regression and naive forecasts. As a rough measure of the statistical significance of the improvement in forecasting ability, we report a t-statistic that tests whether, across forecasts, the sum of the forecast errors is correlated with the difference between the errors. This test is equivalent to a test of equality of mean square forecast errors under the assumptions that the individual forecasts are unbiased and the forecast errors are not autocorrelated [see, e.g., Granger and Newbold (1977)]. 23 We report results for both monthly and annual one-stepahead forecasts. 
The results for the one-step-ahead annual forecasts are reported in the last column of table 7 . We define the percentage reduction in mean square forecast errors as $100 \times\left(M S E_{1}-M_{2} E_{2}\right) / M S E_{1}$, where $M_{S E}$ is the mean square error of one-step-ahead forecasts based on the previous historical average, and $\mathrm{MSE}_{2}$ is based on the one-step-ahead forecasts from the regression

$$
\left(\tilde{R}_{\text {ASSET }}-R_{T B}\right)_{t}=a_{0}+a_{1}\left(\overline{-\log P_{Q 1}}\right)_{t-1}+\tilde{u}_{t} .
$$

The base period for both sets of forecasts begins in 1927.

The improvement in one-year-ahead forecasting ability with equation (5), as indicated by the percentage reduction in MSE in the last column in table 7 , is impressive--particularly for the bonds (17\% to $27 \%)$ and small stocks (12\%). The t-statistics, although generally not large, do suggest reliable improvement in forecasting ability for the lower-grade bonds. 24

The results for the one-month-ahead forecasts are reported in the first three columns in table 7. Mean square forecast errors are computed over all months as well as separately for January and February-December in order to examine seasonal patterns in forecasting ability. We define the percentage reduction in MSE for one-month-ahead forecasts as $100 \times\left(\mathrm{MSE}_{1}-\mathrm{MSE}_{2}\right) / \mathrm{MSE}_{1}$, where $M S E_{1}$ is the MSE of the one-month-ahead forecast based on the regression,

$$
\left(\tilde{R}_{A S S E T}-R_{T B}\right)_{t}=a_{0 j} d_{j t}+a_{0 r}\left(1-d_{j t}\right)+\tilde{u}_{t},
$$

and $\mathrm{MSE}_{2}$ is based on the regression (estimated with WLS),

$$
\begin{aligned}
\left(\tilde{R}_{\text {ASSET }}\right. & \left.\left.-R_{T B}\right)_{t}=a_{0 j} d_{j t}+a_{O r}\left(1-d_{j t}\right)+a_{i j} d_{j t} \overline{\left(-\log P_{Q 1}\right.}\right)_{t-1}+ \\
& +a_{1 r}\left(1-d_{j t}\right)\left(\overline{-\log P_{Q 1}}\right)_{t-1}+\tilde{u}_{t},
\end{aligned}
$$


where $d_{j t}$ is a January dummy. Thus our naive forecasting model, represented by equation (6), accounts for the seasonal variation in the (unconditional) mean of past returns, while the model of equation (7) also acounts for seasonal variation in conditional mean returns given the level of small firm prices. We report results for our seven asset categories as well as for the return differences discussed in section 4.2 .

The results for the one-month-ahead forecasts show that, for the stocks and for the lower-grade bonds, most of the improvement in forecasting ability using equation (7) arises from the January forecasts. Thus, these results support the regression estimates reported in section 4 . The improvement in January ranges from an $11 \%$ reduction in MSE for large firm stocks to $42 \%$ for small firm stocks: The $t$ statistics for the three stock portfolios indicate statistically reliable reductions in MSE. In February-December, however, the naive forecast for the lowest grade bonds and all three stock portfolios outperforms the forecast based on equation (7). A similar pattern is observed for differences in returns of similar assets: the improvements in January forecasting ability are $28 \%$ for UBAA minus LTGOV and $41 \%$ for Q1 minus Q5. For the long-term government and high-grade corporate bonds, on the other hand, forecasting ability is not concentrated in January. Overall, the results suggest that the forecasting model in equation (7) possesses predictive ability for a wide array of asset returns.

\section{Implications for Future Research}

The fundamental conclusion to be drawn from this study is that expected risk premiums on many assets appear to change over time in a manner that is at least partially described by variables that reflect levels of asset prices. The implied directions for future research are several. 
If expected risk premiums or discount rates change, then one asset's price relative to others is determined in part by the covariance between unanticipated returns on that asset and unanticipated changes in expected risk premiums. Chen, Roll, and Ross (1983), in a test of such a cross-sectional pricing relation, propose a bond return spread (decribed earlier) as a proxy for changes in expected risk premiums. This study's evidence suggests that such a variable is indeed likely to proxy for changes in expected $r$ isk premiums on many assets. If relative bond prices, say as summarized by the yield spread used in this study, contain ex ante information about expected risk premiums, as our evidence indicates, then a change in relative bond prices, or a return difference, is likely to contain ex post information about changes in expected premiums. By the same reasoning, our evidence that levels of stock prices also contain information about expected risk premiums suggests that stock returns also contain information about changes in expected premiums.

Given that most pricing models call for conditional rather than unconditional moments, the ex ante variables used here are candidates for prewhitening many return series to obtain deviations from conditional means. For example, conditional covariances between prewhitened series, rather than unconditional covariances, are generally the relevant risk measures ( $\beta_{i k}{ }^{\prime} s$ ) in models as in (1).25 For many assets, where the explanatory power of the regressions in sections 3 and 4 is relatively low, the distinction may be minor. For other assets, however, where the explanatory power is higher, e.g., January returns on small-firm stocks and low-grade bonds, the distinction between conditional and unconditional cross-sectional risk measures may prove to be important.

In addition to conditional risk measures, conditional means themselves 
may allow more precise inferences about various hypotheses. For example, the evidence on term premiums discussed in section 3.3 indicates that the relation between conditional expected bond returns and time to maturity varies through time. The difference in conditional expected return between long-term and short-term bonds appears to vary inversely with asset price levels. Conditional on sufficiently low asset prices, or perhaps sufficiently high risk, the estimated regressions suggest that the term structure slopes upward. If true, such behavior could make unconditional averages of term premiums less useful in making inferences about the shape of the term structure.

One question that arises naturally in a study such as this is whether additional ex ante variables have predictive ability. We have chosen to define this study by restricting the number of ex ante variables and examining risk premiums on a wide spectrum of assets, but the investigation could be extended across a range of ex ante variables as well. A possible approach would be to decompose our variables into several components. For example, the single yield spread could be replaced by a number of yield spreads between instruments of various default risks and maturities.

Finally, we conclude that seasonality must be a consideration of any study dealing with changing expectations. Not only is seasonality present in average risk premiums on many assets, conditioned on simply the month of the year, but seasonality is found also in the regression coefficients on the ex ante variables that appear to predict risk premiums. 


\section{FOOTNOTES}

1 Examples of such models include the Capital Asset Pricing Model of Sharpe (1964) and Lintner (1965); the intertemporal models of Merton (1973), Long (1974), Cox, Ingersoll, and Ross (1985), Lucas (1978), and Breeden (1979); and the Arbitrage Pricing Theory of Ross (1976).

2 See, for example, Bodie (1976), Jaffe and Mandelker (1976), Nelson (1976), and Fama and Schwert (1977). The negative correlation is particularly strong when the measure of expected inflation is simply the Treasury bill rate, as in the last study, but the phenomenon is evidently confined to the post-1953 period. For example, a regression of excess returns for the valueweighted NYSE on the one-month T-bill return [from Ibbotson and Sinquefield (1982) ] yields a coefficient of -2.81 with a $t$ statistic of -3.28 in the 195381 period, but the same regression in the $1926-52$ period yields a coefficient
of -0.89 with a t statistic of -0.25 .

3 One of the measures, the yield spread between long-term Government bonds and Treasury bills, is used earlier by Shiller, Campbell, and Schoenholtz (1983) to predict excess returns on long-term bonds.

4 In some cases, the discount rate will simply be an average of expected future returns, such as when expected future returns are nonstochastic [e.g. Fama (1977)]. In more general models, (2) would include covariances between expected returns and cash flows, such as the valuation equation in Cox, Ingersoll, and Ross (1985),

$$
p_{t}=E\left\{\int_{t}^{\infty} c(s) e^{-d(s ; t)} d s\right\} \text {, }
$$

where the "discount" rate $d(s ; t)$ depends on the expected return for time
$u, B(u)$, through

$$
d(s ; t)=\int_{t}^{s} B(u) d u \text {. }
$$

${ }^{5}$ In a cross-sectional study, Miller and Scholes (1982) propose the reciprocal of share price as a proxy for expected returns.

${ }^{6}$ The below-BAA yield series is obtained from Ibbotson (1978). We do not use actual one-month T-bill yields; rather, we use the one-month return on the Ibbotson-Sinquefield (1982) T-bill series. This series is based on the lowest maturity T-bill available with at least one month maturity. Prior to 1938 , the maturity is often two to three months. [See also Ibbotson and Sinquefield (1976).] Nevertheless, the yield difference series wanders slowly enough so that the one-month T-bill variable we use should produce results very similar to those with actual ex ante observable T-bill yields. Both the yield difference and the stock price variables (defined below) possess high autocorrelations, at least 0.95 at the first order and decaying slowly at higher orders. When the regressions reported below are run instead on the same variables lagged several months, the results are very similar to those shown, with explanatory power dropping gradually as lags increase. 
7 Detrending with ex post prices would most likely bias our results in favor of finding predictive ability.

${ }^{8}$ Correlations between monthly levels range from .71 to .83 ; correlations between monthly first differences range from .26 to .75 .

${ }^{9}$ As in Merton (1980), the monthly variance is the sum of squared differences in log prices, where each squared difference is divided by the number of days between trades (to adjust for holidays and weekends).

${ }^{10}$ Correlations between the standard deviation and the ex ante variables range from .41 to .62 ; first differences are correlated from .01 (the yield

${ }^{11}$ Stock returns data are obtained from CRSP. To create quintiles, we rank in ascending order all NYSE firms on their market value of common equity (the product of price per share and number of shares outstanding) at the end of the previous year. Firms within a quintile are weighted, for a given month $t$, by placing equal weights on each stock at the beginning of month $t-1$. The month $t$ weights are then the second-month weights in a two-month buy-and-hold strategy. This reduces the bid-ask bias, as discussed by Blume and Stambaugh
(1983).

${ }^{12}$ Most of our series begin in 1/1926, and the low-grade bond series (BAA and below-BAA) end in 1978. The annual regressions reported below in 3.2, given that they require year-end data, are confined to the 1927-1977 period. The monthly regressions reported below in section 4 use weighted least squares, and the weights (the $S \& P$ standard deviation) begin in $1 / 1928$. Thus the 1/1927 - 11/1978 period includes the data used in any of our tests.

${ }^{13}$ Stambaugh (1985) investigates the bias when the independent variable obeys a first-order autoregressive process. He finds that the (absolute) bias increases with both the autocorrelation in the independent variable and the correlation of the regression disturbance with the innovation in the
independent variable.

14 We thank Gene Fama for sharing this data.

${ }^{15}$ A similar conclusion is reached by McCulloch (1975).

16 The estimates were produced by an iterative procedure (PROC SYSNLIN) in the SAS computer program.

${ }^{17}$ The t-statistic $t\left(a_{0}-a_{1}\right)$ in the third column of each period's results tests the hypothesis that the difference in means is zero. In the overall period, the t-statistics for LTCORP, BAA, UBAA, Q3 and Q1 have p-values less

${ }^{18}$ Low prices might also indicate previous tax losses, thereby supporting the hypothesis that the January returns reflect a rebound from tax-loss selling pressure. Roll (1983) finds that returns on an equally-weighted stock index in the preceding year are negatively correlated with returns surrounding the turn of the year, and he suggests a tax-loss selling explanation for these results. We do not attempt to rule out such an explanation. Rather, we 
simply suggest an alternative, perhaps additional, source of the observed phenomenon. Reinganum (1983, p. 102) concludes that "potential tax-loss selling does not seem capable of explaining the entire anomolous return behavior of small firms in January." Chan (1985) finds that, cross sectionally, returns in a given year are negatively correlated with January returns two years hence, and he also concludes that tax selling cannot be the sole explanation of the observed seasonality.

${ }^{19}$ For example, using daily returns on firms in the lowest twentieth of all NYSE and AMEX firms ranked by size, Rogalski and Tinic (1984) report OLS beta estimates of 1.34 in January as compared to 1.01 in the next highest months (February and December). We have found (in unpubiished work) that alternative samples and estimation methods yield a similar seasonal pattern. To explain the seasonality in average returns using the traditional asset pricing theory, however, such relatively small changes in beta require an implausibly high market risk premium.

${ }^{20}$ See, for example, Krasker (1980).

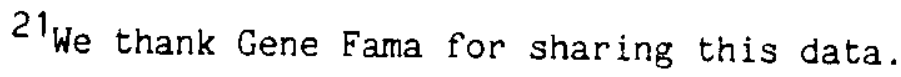

22 These delistings are those for which there was no notice of delisting prior to the given month, as classified by CRSP. Roll (1983) also observes that delistings occur more frequently near January 1.

${ }^{23}$ The $t$ statistic is "rough" in the sense that, if the true forecasting ability of our regression model is zero, then the variance of the forecast errors from the naive model is less than the variance of our regression forecast errors, due to the extra noise that results from estimation of additional parameters in the latter model. Thus, the expected value of the $t$ statistic reported here is negative with no forecasting ability. Finding $t$ statistics equal to zero is actually mild evidence of some predictive ability.

${ }^{24}$ Recalling the discussion in footnote 21 , the correct p-values are less than those implied by the statistics we report.

${ }^{25}$ Two exceptions, in which unconditional covariances are appropriate even if there exist ex ante variables with predictive ability, are the models in Grossman and Shiller (1982) and Stambaugh (1983). 


\section{REFERENCES}

Blume, Marshall E. and Stambaugh, Robert E. "Biases in Computed Returns: An Application to the Size Effect." Journal of Financial Economics 12 (November 1983): 387-404.

Bodie, 2vi. "Common Stocks as a Hedge against Inflation." Journal of Finance 31 (May 1976): 459-70.

Breeden, Douglas T. "An Intertemporal Asset Pricing Model with Stochastic Consumption and Investment Opportunities." Journal of Einancial Economics 7 (September 1979): 265-96.

Campbell, John Y. "Stock Returns and the Term Structure." Unpublished manuscript. New Haven: Yale University, 1984.

Chan, K. C., "Can Tax-Loss Selling Explain the January Seasonal in Stock Returns?" Unpublished manuscript. Columbus: Onio State University, 1985.

Chan, K. C.; Chen, Nai-Fu; and Hsieh, David. "An Exploratory Investigation of the Eirm Size Effect." Working Paper no. 99. Chicago: Center for Research in Security Prices, University of Chicago, 1983.

Chen, Nai-Fu; Roll, Richard; and Ross, Stephen A. "Economic Forces and the Stock Market: Testing the APT and Alternative Asset Pricing Theories." Unpublished manuscript. Chicago: University of Chicago, 1983.

Cox, John C.; Ingersoll, Jonathan E.; and Ross, Stephen A. "An Intertemporal General Equilibrium Model of Asset Prices." Econometrica 53 (March 1985): 363-384.

Fama, Eugene F. "Risk-Adjusted Discount Rates and Capital Budgeting Under Uncertainty." Journal of Einancial Economics 5 (August 1977): 3-24.

Fama, Eugene F. "Stock Returns, Real Activity, Inflation, and Money." American Economic Review 71 (September 1981): 545-565.

Fama, Eugene F. "Term Premiums in Bond Returns." Journal of Financial Economics 13 (December 1984a): 529-546.

Fama, Eugene F. "Term Premiums and Default Premiums in Money Markets." Working Paper no. 135. Chicago: Center for Research in Security Prices, $1984 b$.

Fama, Eugene F. and Schwert, G. William. "Asset Returns and Inflation." Journal of Financial Economics 5 (November 1977): 115-46.

Fisher, Lawrence. "Some New Stock Market Indices." Journal of Business 49 (Supp., January 1966): 191-225.

Granger, C.W.J., and Newbold, Paul. Forecasting Economic Time Series. New York: Academic Press, 1977.

Grossman, Sanford J. and Shiller, Robert J. "The Determinants of the Variability of Stock Market Prices." American Economic Review 71 (May 
Grossman, Sanford J., and Shiller, Robert J., "Consumption Correlatedness and Risk Measurement in Economies with Non-Traded Assets and Heterogeneous Information," Journal of Financial Economics 10 (July 1982): 195-210.

Ibbotson, Roger G. "The Corporate Bond Market: Structure and Returns." Unpublished manuscript. Chicago: University of Chicago, 1979.

Ibbotson, Roger G. and Sinquefield, Rex A. "Stocks, Bonds, Bills, and Inflation: Year-by-Year Historical Returns (1926-1974)." Journal of Business 49 (January 1976): 11-47.

Ibbotson, Roger G. and Sinquefield, Rex A. "Stocks, Bonds, Bills and Inflation: The Past and the Future." Charlottesville, VA: Financial Analysts Research Foundation, 1982.

Jaffe, Jeffrey F. and Mandelker, Gershon. "The ' $E$ isher Effect' for Risky Assets: An Empirical Investigation." Journal of Finance 31 (May 1976): 447-58.

Keim, Donald B. "Size-Related Anomalies and Stock Return Seasonality: Further Empirical Evidence." Journal of Financial Economics 12 (June 1983): 13-32.

Keim, Donald B., and Smirlock, Michael. "Bond Returns, Firm Size and Abnormal January Returns." Unpublished manuscript. Philadelphia: University of Pennsylvania, 1983.

Krasker, William S. "The 'Peso Problem' in Testing Efficiency of the Forward Exchange Markets." Journal of Monetary Economics 6 (April 1980): 269276.

Leroy, Stephen F. and Porter, Richard D. "The Present-Value Relation: Tests Based on Implied Variance Bounds." Econometrica 49 (May 1981): 555-574.

Lintner, John. "The Valuation of Risk Assets and the Selection of Risky Investments in Stock Portfolios and Capital Budgets." Review of Economics and Statistics 47 (February 1965): 13-37.

Long, John B. "Stock Prices, Inflation, and the Term Structure of Interest Rates." Journal of Financial Economics 1 (July 1974): 131-170.

Lucas, Robert E. "Asset Prices in an Exchange Economy." Econometrica 46 (November 1978): 1429-46.

McCulloch, J. Huston. "An Estimate of the Liquidity Premium." Journal of Political Economy 83 (February 1975): 95-119.

Merton, Robert C. "An Intertemporal Capital Asset Pricing Model." Econometrica 41 (September 1973): 867-87.

Merton, Robert C. "On Estimating the Expected Return on the Market: An Exploratory Investigation." Journal of Financial Economics 8

(December 1980): 323-361. 
Miller, Merton H., and Scholes, Myron S. "Dividends and Taxes: Some Empirical Evidence." Journal of Political Economy 90 (December 1982): $1118-41$.

Nelson, Charles R. "Inflation and Rates of Return on Common Stock." Journal of Finance 31 (May 1976): 471-83.

Reinganum, Marc R. "The Anomalous Stock Market Behavior of Small Firms in January." Journal of Financial Economics 12 (June 1983): 89-104.

Rogalski, Richard J. and Tinic, Seha M. "The January Size Effect: Anomaly or Risk Mismeasurement?" Unpublished manuscript. Hanover: Dartmouth College, 1984.

Roll, Richard. "Vas Ist Das? The Turn of the Year Effect and the Return Premia of Small Firms." Journal of Portfolio Management 9 (Winter 1983): 18-28.

Ross, Stephen A. "The Arbitrage Theory of Capital Asset Pricing." Journal of Economic Theory $13(1976): 341-60$.

Rozeff, Michael S., and Kinney, William R., Jr. "Capital Market Seasonality: The Case of Stock Returns." Journal of Financial Economics 3 (October 1976): 379-402.

Schneeweiss, Thomas, and Woolridge, J. Randall. "Capital Market Seasonality: The Case of Bond Returns." Journal of Financial and Quantitative Analysis 14 (December 1979): $\frac{\text { 939-958. }}{939}$

Schwert, G. William. "Size and Stock Returns, and Other Empirical Regularities." Journal of Financial Economics 12 (June 1983): 3-12.

Sharpe, William F. "Capital Asset Prices: A Theory of Market Equilibrium under Conditions of Risk." Journal of Finance 19 (September 1964):
425-42.

Shiller, Robert J. "Do Stock Prices Move Too Much to be Justified by Subsequent Changes in Dividends? American Economic Review 71 (June 1981): $421-436$.

Shiller, Robert J.; Campbell, John Y.; and Schoenholtz, Kermit L. "Forward Rates and Future Policy: Interpreting the Term Structure of Interest Rates." Brookings Papers on Economic Activity $(1: 1983):$ 173-223.

Stambaugh, Robert F. "Arbitrage Pricing with Information." Journal of Financial Economies 12 (November 1983): 357-369.

Stambaugh, Robert F. "An Investigation of Bias in Regressions with Predetermined but Stochastic Regressors." Unpublished manuscript. Chicago: University of Chicago, 1985.

White, Halbert. "A Heteroskedasticity-Consistent Covariance Matrix Estimator and a Direct Test for Heteroskedasticity." Econometrica 48 (May 1980):
$817-838$. 


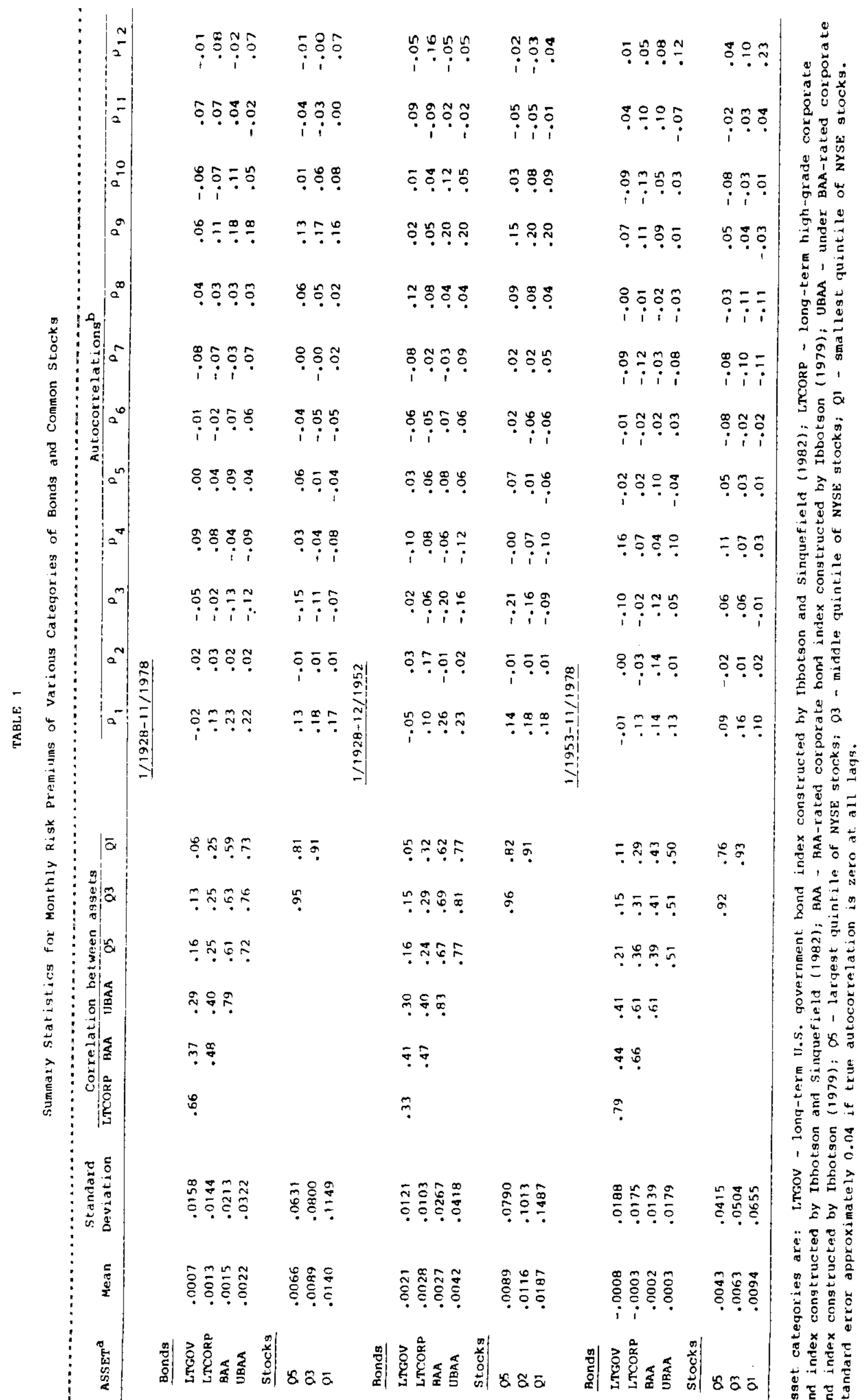




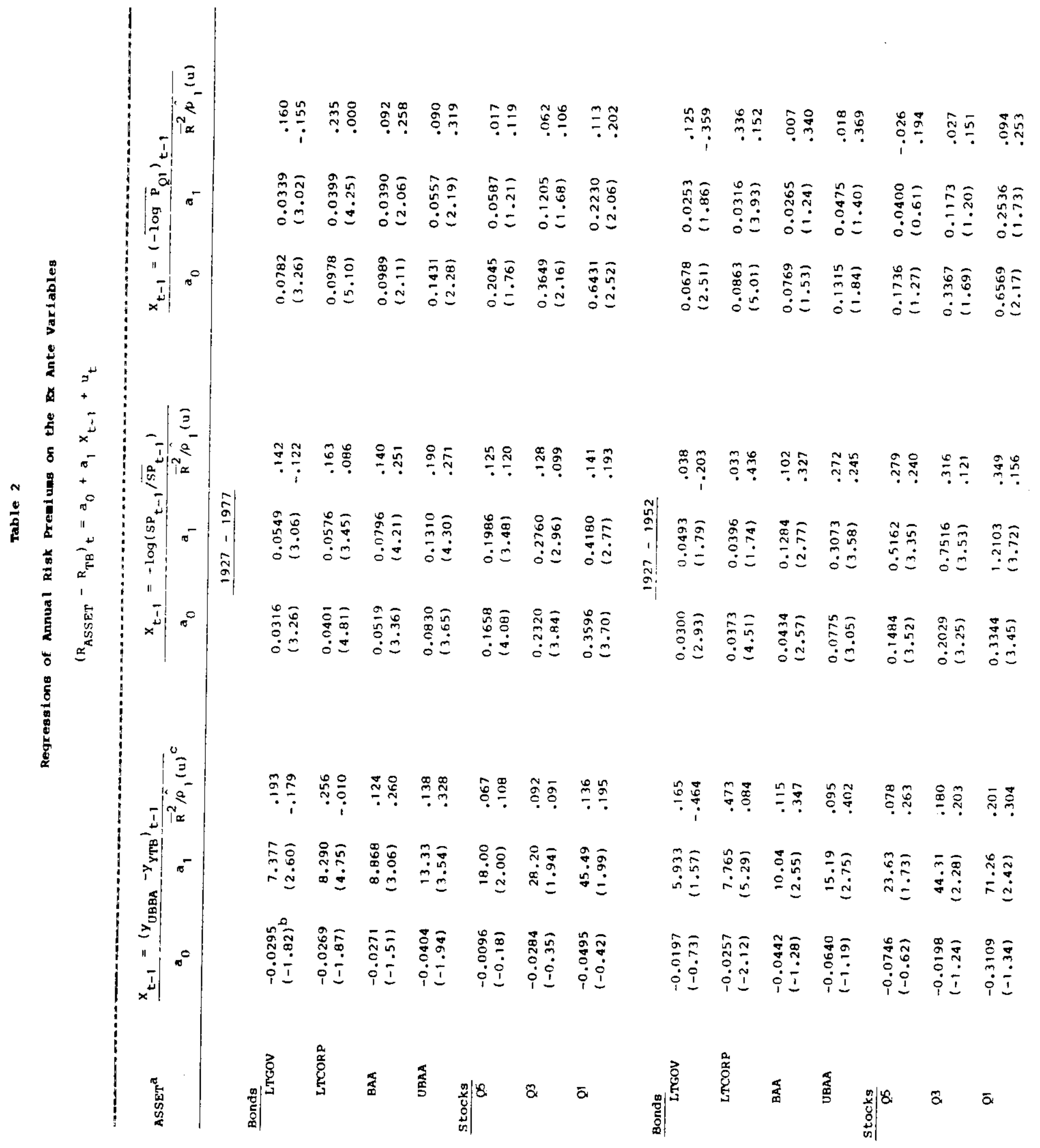




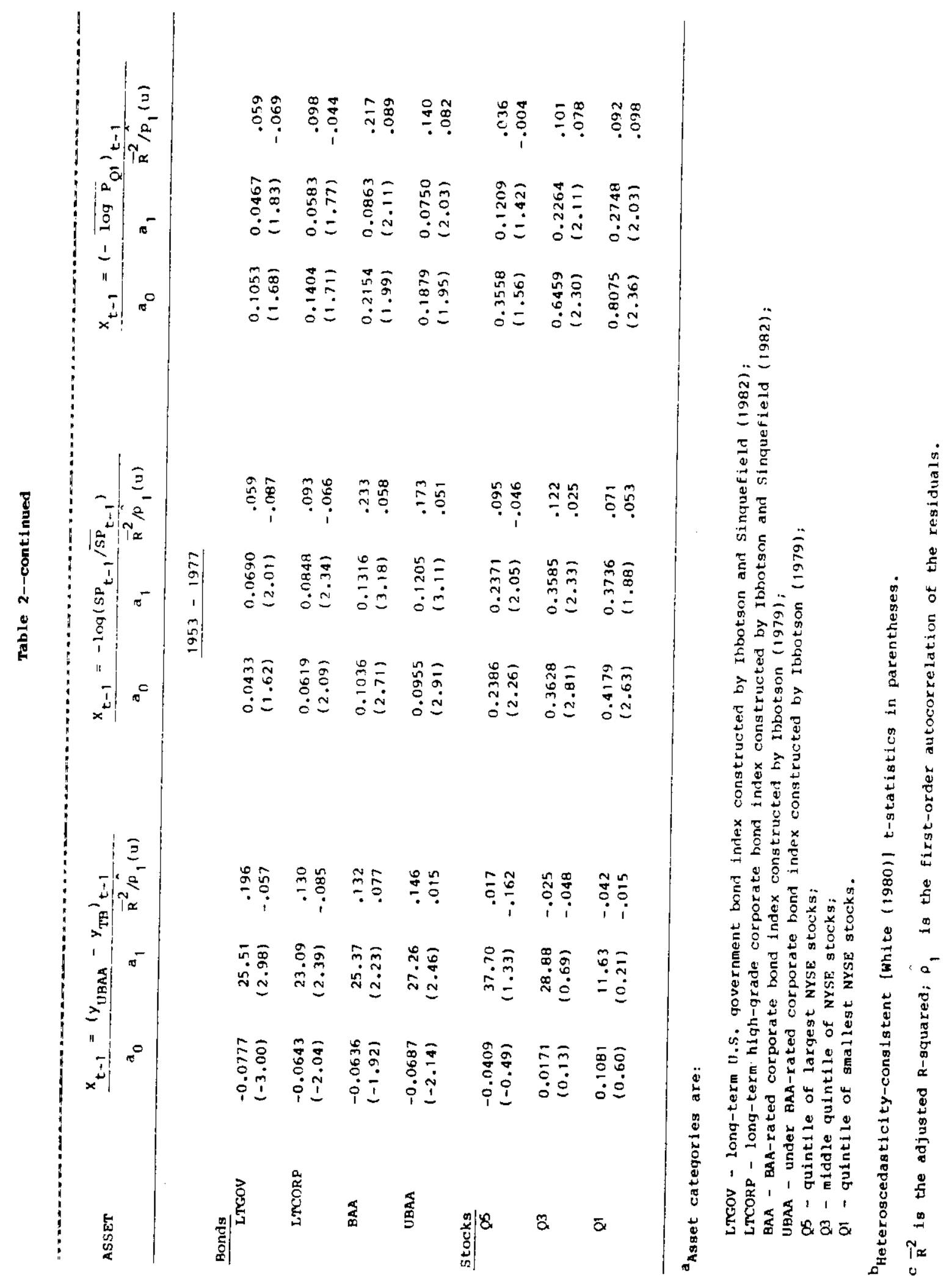




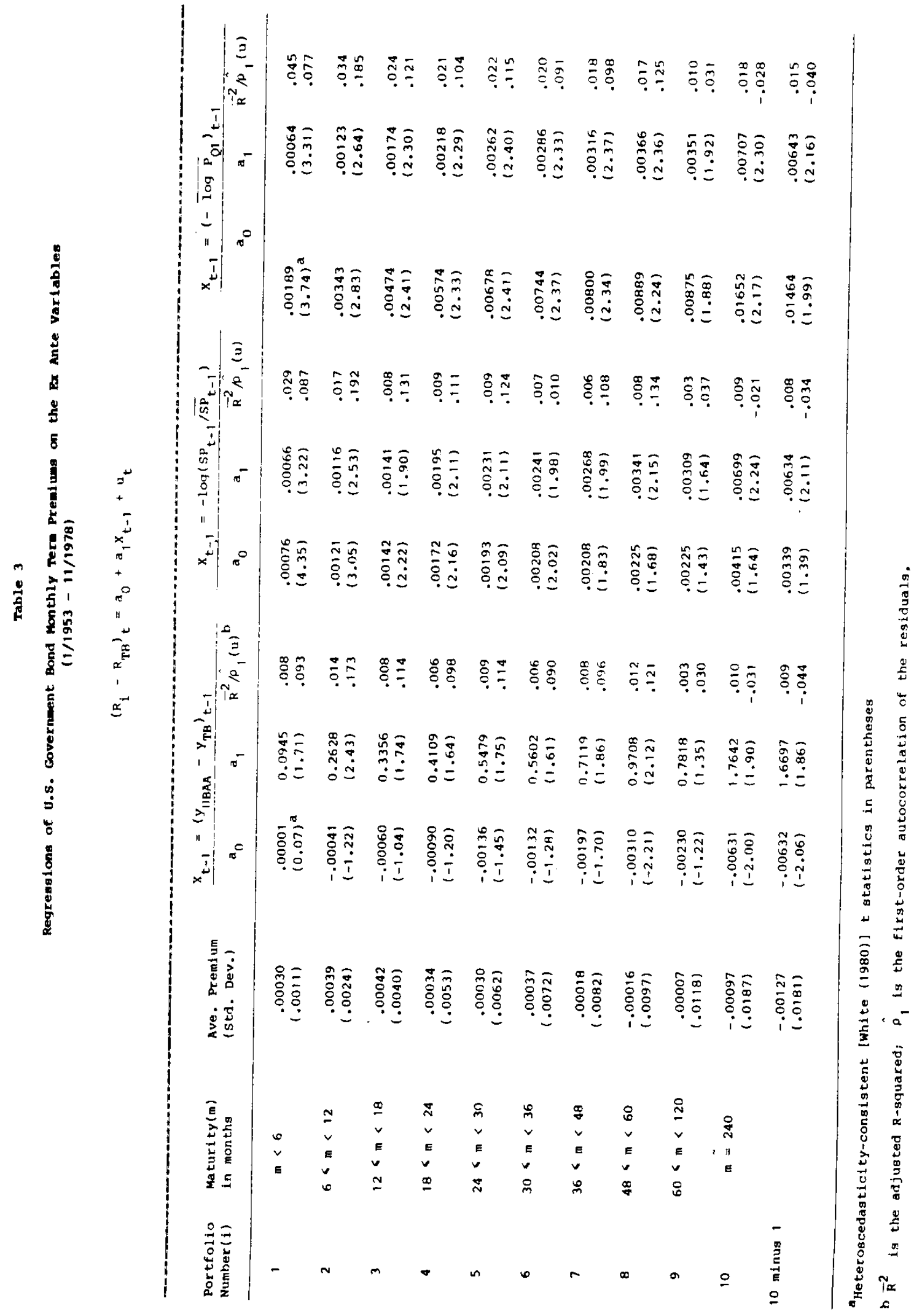




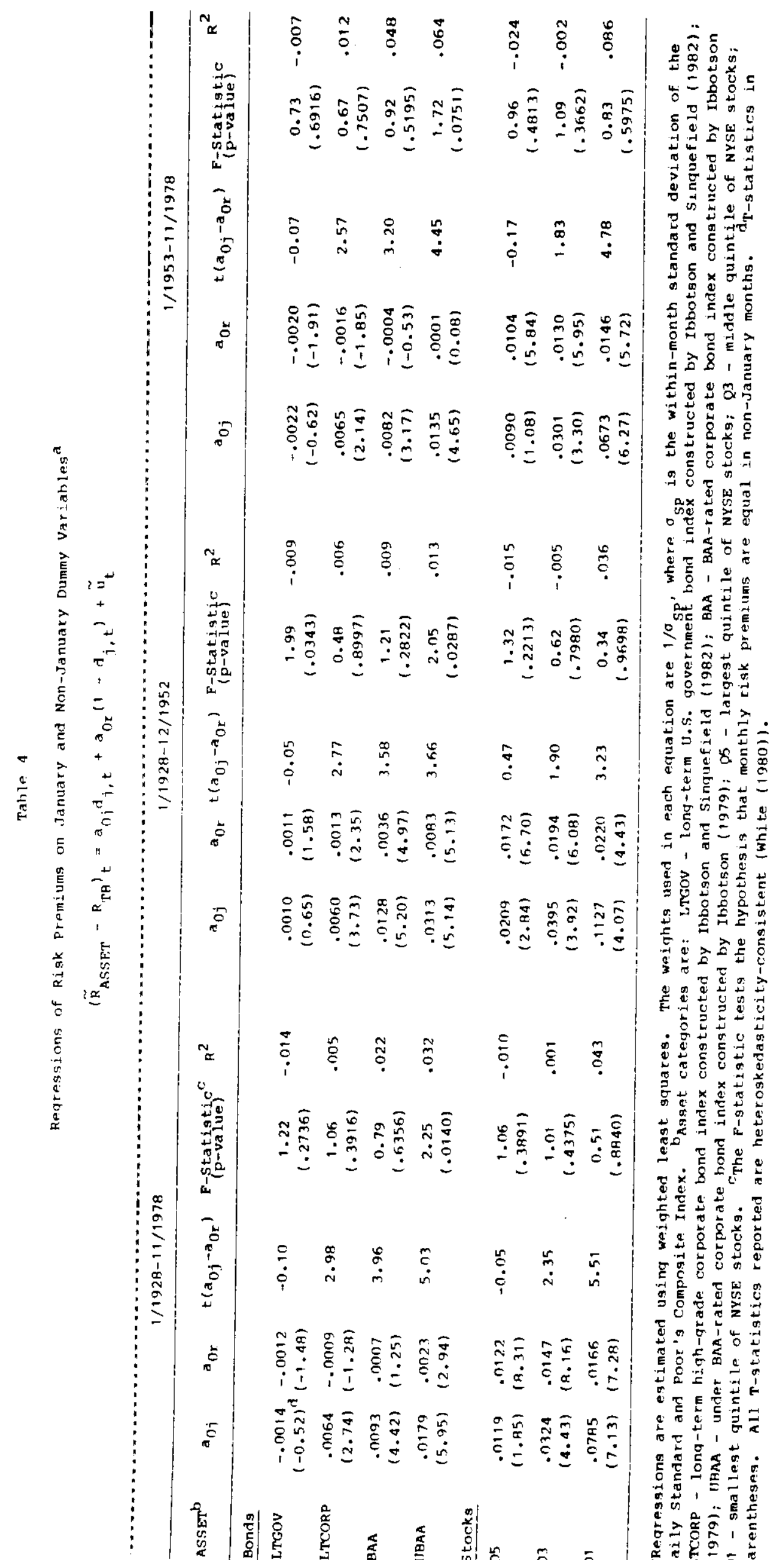




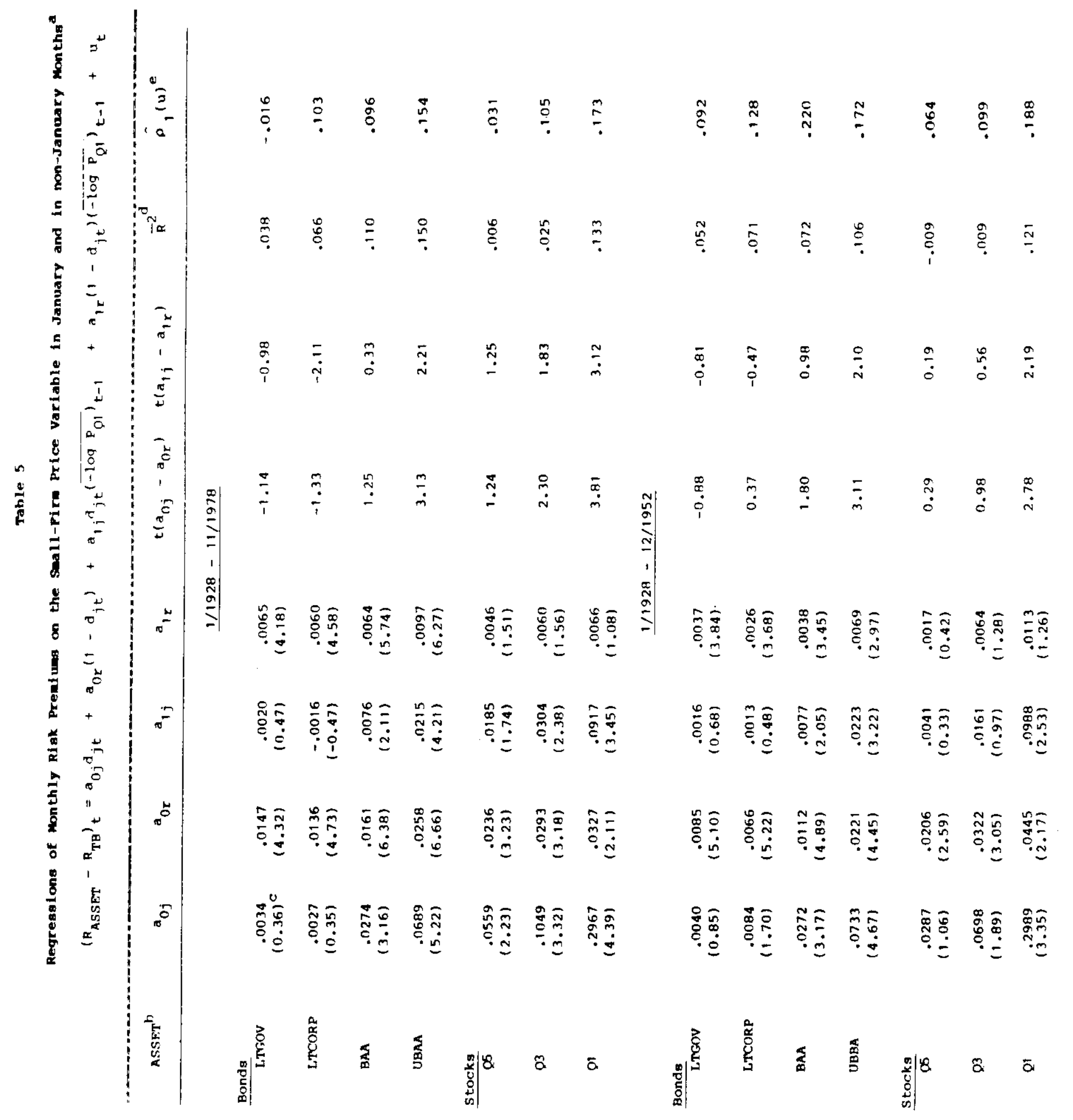




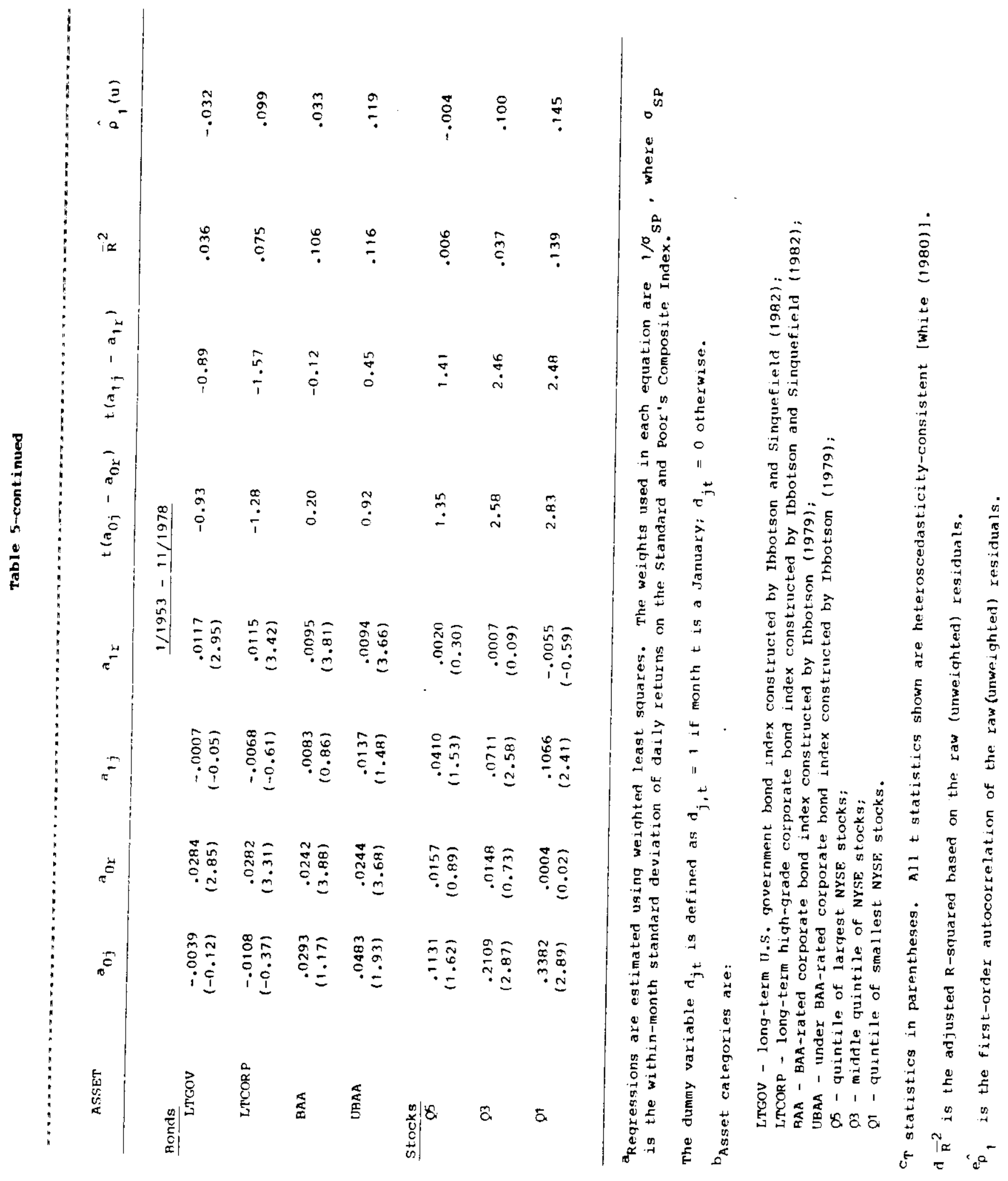




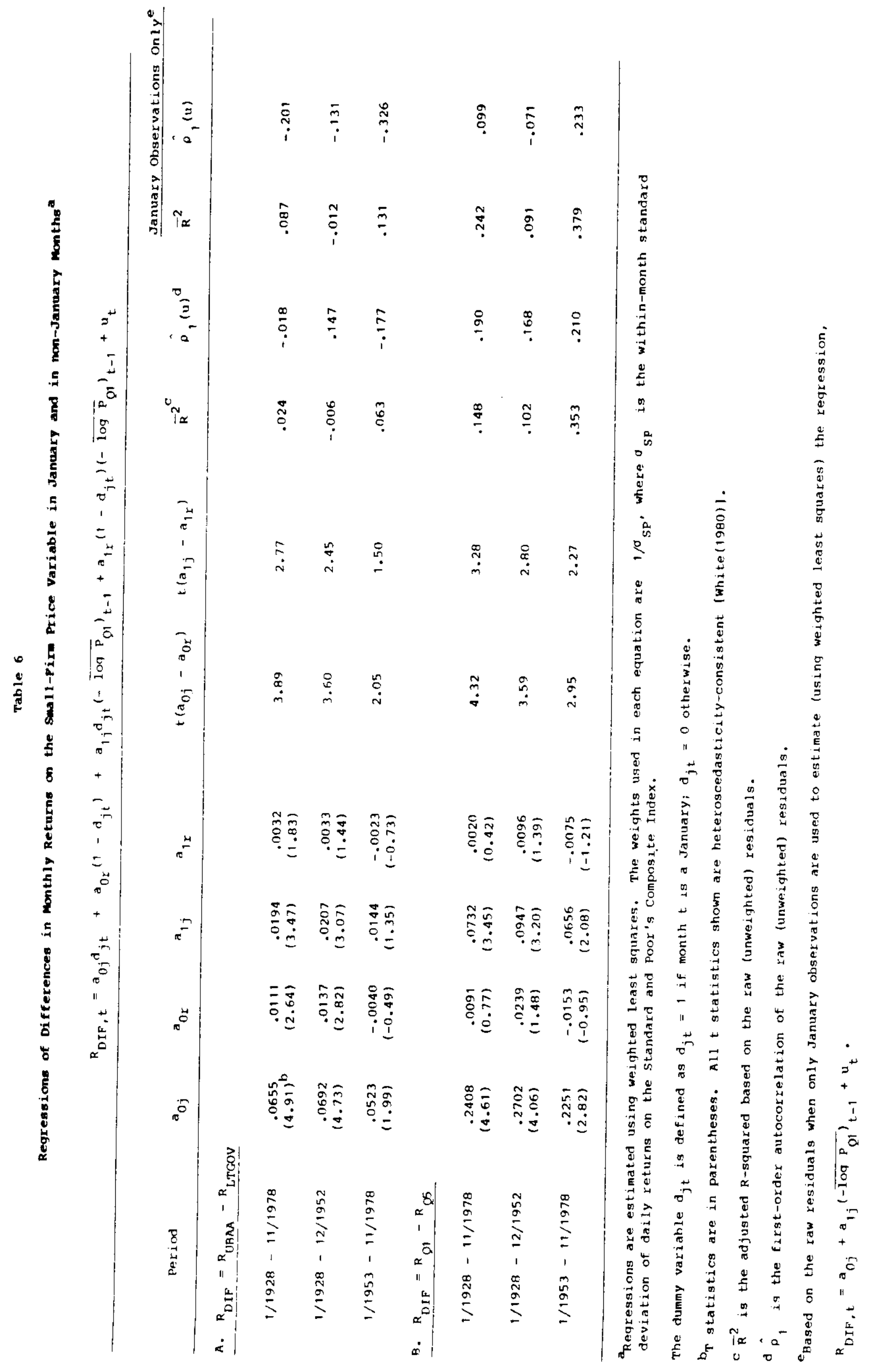


Table 7

Performance of One-step-Ahead Forecasts Based

on the Small-Firm Price variable

$(1953$ - 1978)

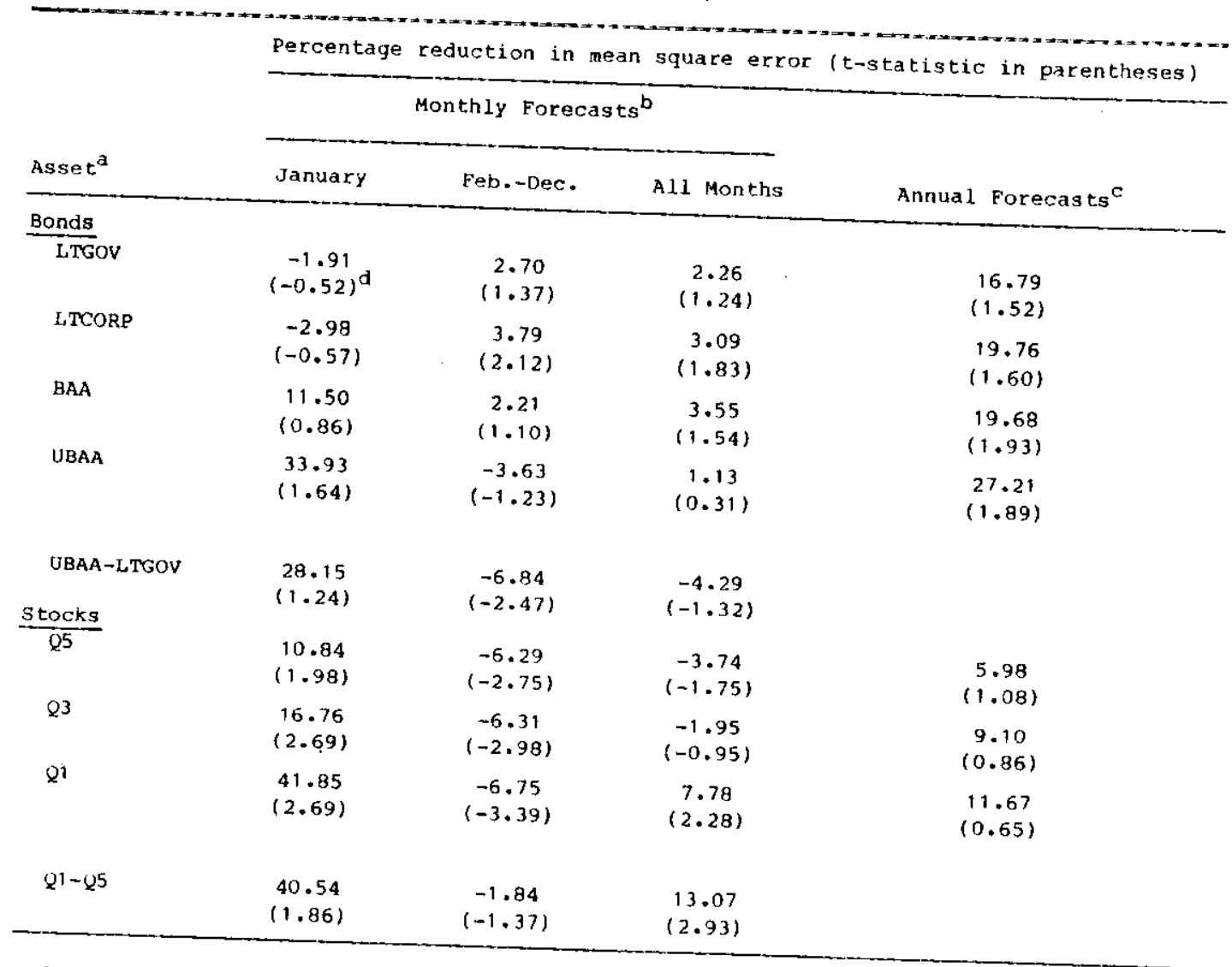

a Asset categories are:

LTGOV - long-term U.S. government bond index constructed by Ibbotson and singuefield

LTCORP -

Sinquefield (1982). corporate bond index constructed by Ibbotson and

UBAA - under BAA-rated corporate index constructed by Ibbotson (1979);

Q5 - quintile of largest NYSE stocks:

Q3 - midale quintile of NYSE stocks;

Q1 - quintile of smallest NYSE stocks b The upper value is $100 \times\left(M S E_{1}-M S E_{2}\right) / M S E_{1}$, where MSE, is the mean square error of one-
step-ahead forecasts based on the regression,

$$
\left(\tilde{\mathrm{R}}_{\mathrm{ASSET}}-\mathrm{R}_{\mathrm{TB}}\right)_{t}=a_{0 j} \mathrm{~d}_{j t}+\mathrm{a}_{0 \mathrm{r}}\left(1-\mathrm{d}_{j t}\right)+\tilde{u}_{t}
$$

and $M S E_{2}$ is based on the regression (estimated with WLS),

$\left(\tilde{R}_{\text {ASSET }}{ }^{-R}{ }_{T B}\right)_{t}=a_{0 j} d_{j t}+a_{O r}\left(1-d_{j t}\right)+a_{1 j} d_{j t}\left(\overline{-\log P_{Q 1}}\right)_{t-1}+a_{i r}\left(1-d_{j t}\right)\left(\overline{-\log P_{Q 1}}\right)_{t-1}+\tilde{u}_{t}$, where $d_{j t}=1$ if month $t$ is a January and $d_{j t}=0$ otherwise. The base period for both
sets of forecasts begins $1 / 1928$.

The upper value is $100 \times\left(M S E_{1}-M S E_{2}\right) / M S E_{1}$, where $M S E_{1}$ is the mean square error of onestep-ahead forecasts from the regression

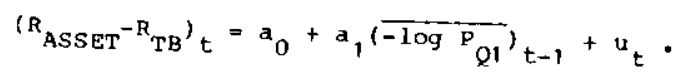

The base period for both sets of forecasts begins in 1927 . d The t-statistic tests whether, across forecasts, the sum of the forecast errors is
correlated with the difference between series produce unbiased errors with the the exrors. The true correlation is zero if hoth test of equality of mean square forecast same variances. This test is equivalent to a 


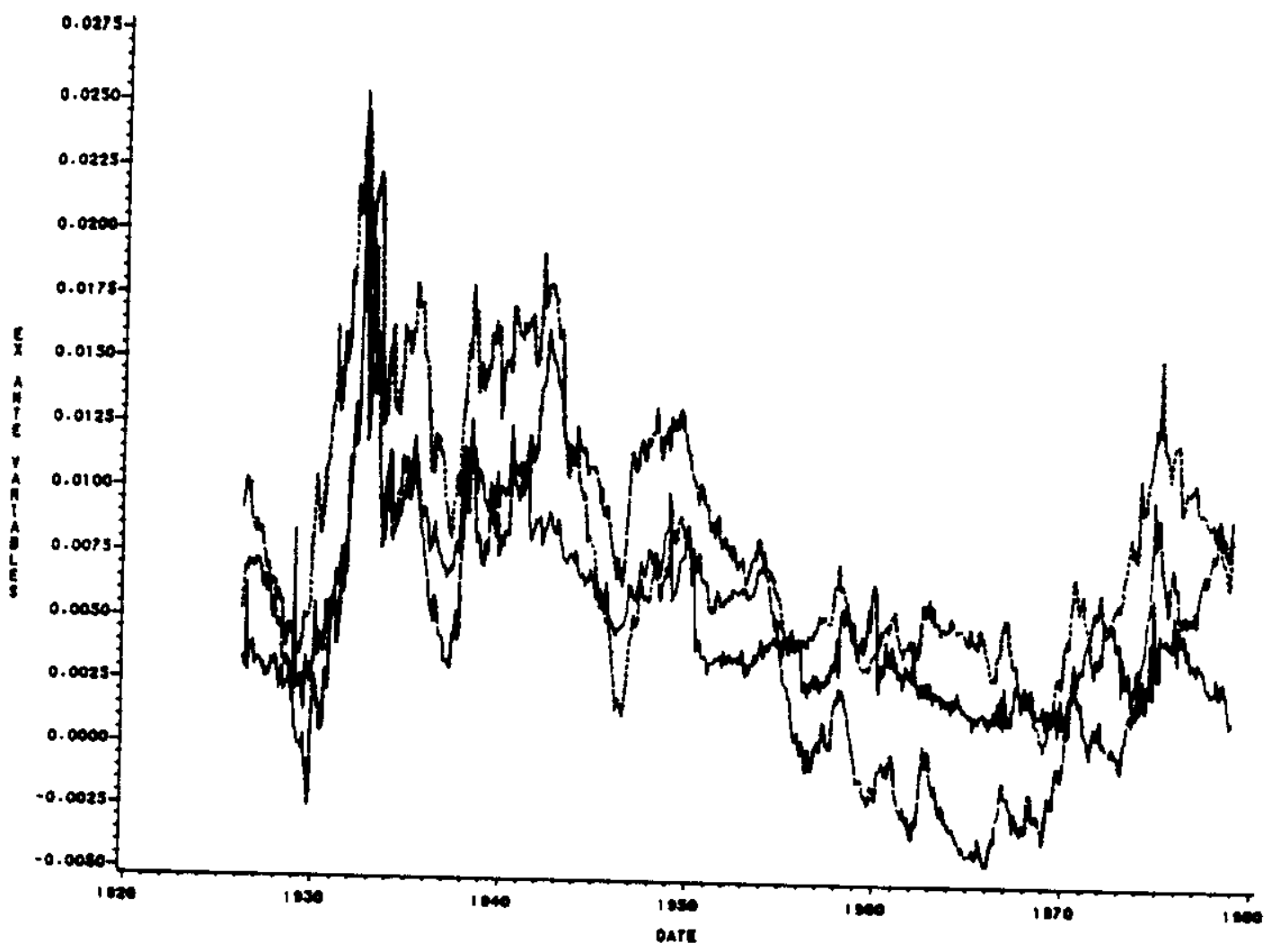

Figuire 1. Monthly time series of the yield variable

(solid line), the $S \& P$ variable (long dashes), and the smallrescaled.)

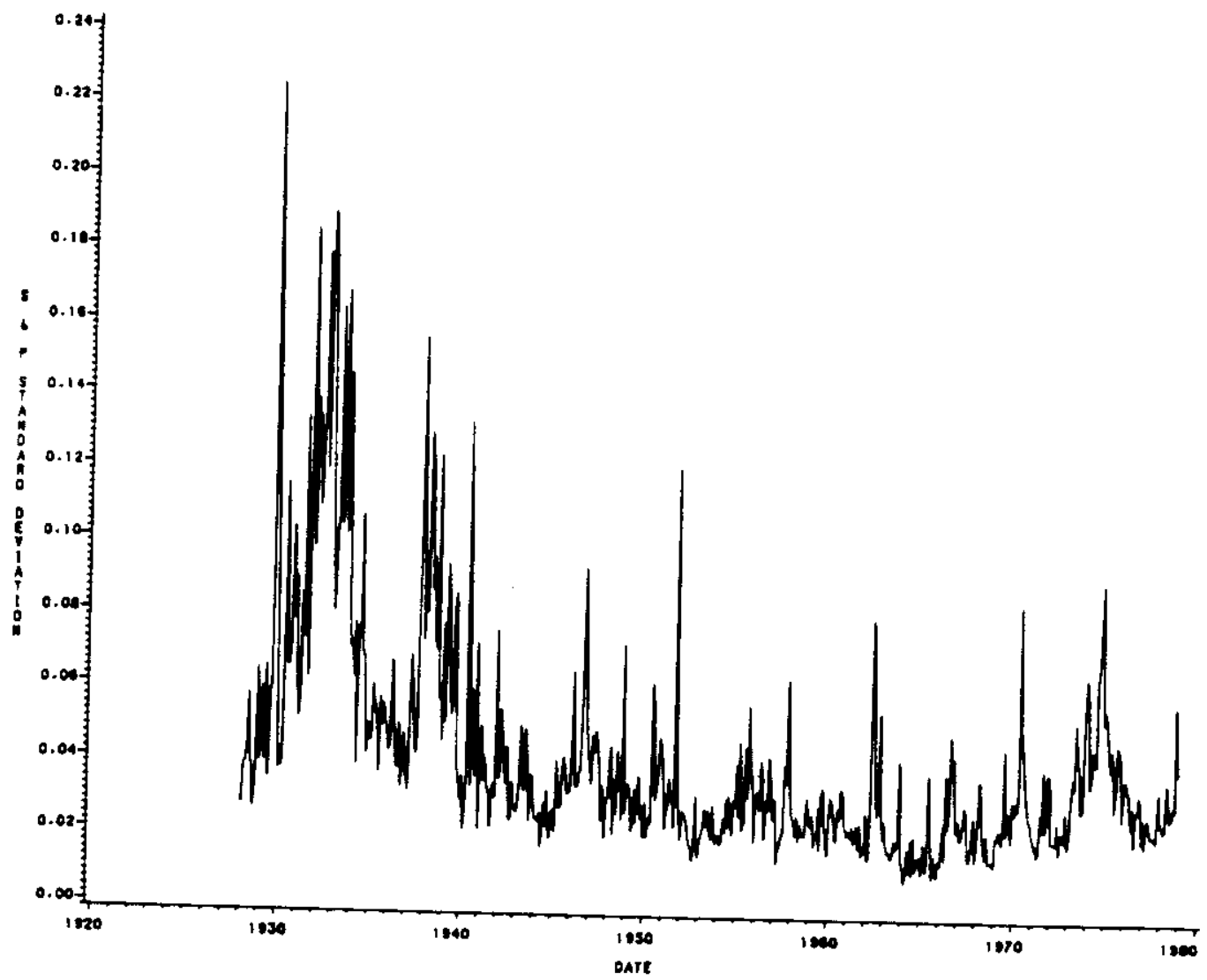

Eigure 2. Monthly time series of the standard deviation of 


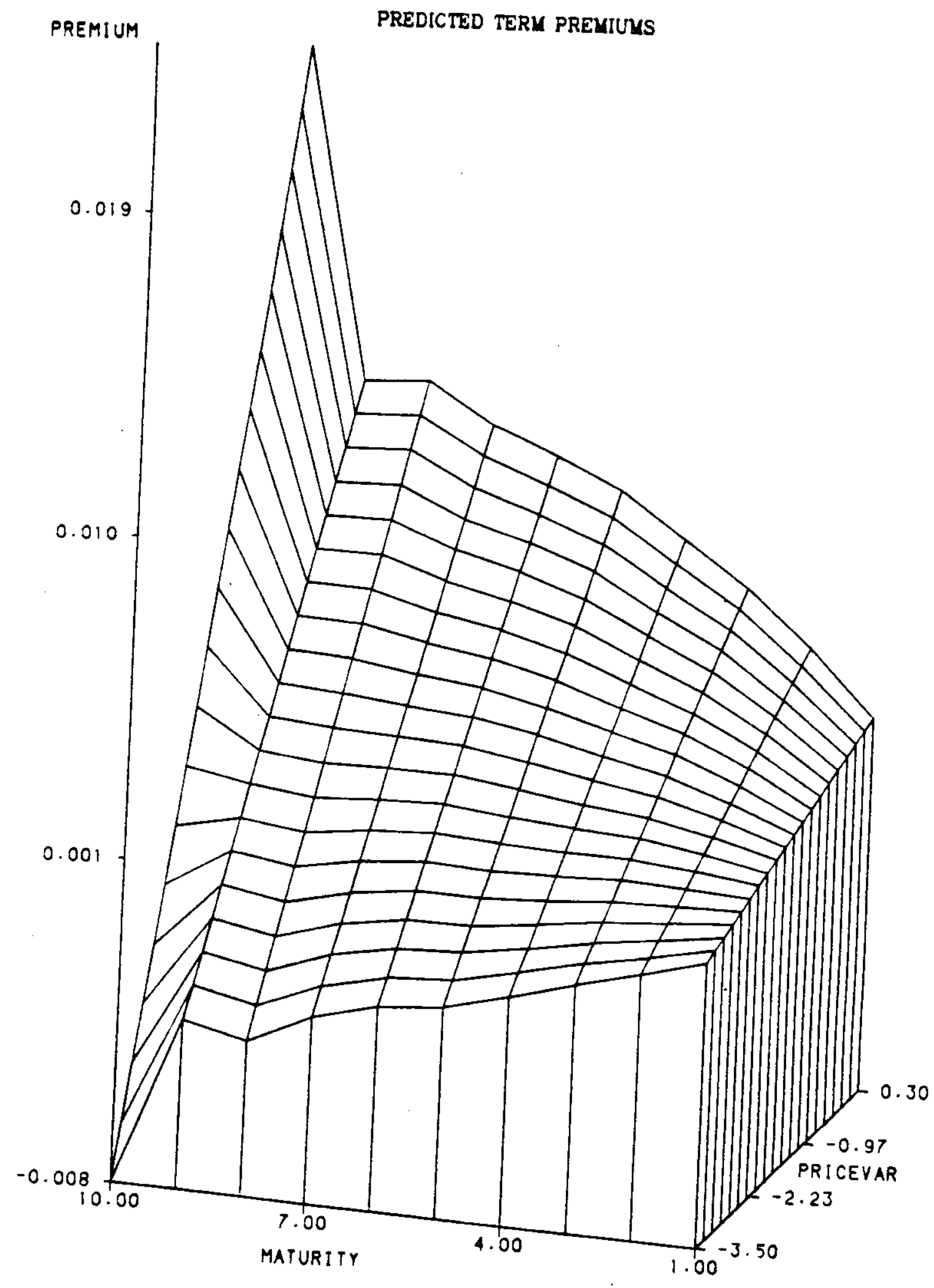
Figure 3. Fitted regressions of term premiums (PREMIUM)
on the small-firm price variable (PRICEVAR) for each of ten
maturity classifications (MATURITY) maturity classifications (MATURITY). 